\title{
B Cell-Activating Factor Regulates Different Aspects of B Cell Functionality and Is Produced by a Subset of Splenic B Cells in Teleost Fish
}

\author{
Carolina Tafalla*, Lucia González, Rosario Castro and Aitor G. Granja* \\ Laboratory of Fish Immunology and Pathology, Centro de Investigación en Sanidad Animal (CISA-INIA), Madrid, Spain
}

OPEN ACCESS

Edited by:

Teizo Yoshimura,

Okayama University, Japan

Reviewed by:

Mohey Eldin El Shikh,

Queen Mary University of London,

Robert J. B. Nibbs,

University of Glasgow, UK

${ }^{*}$ Correspondence:

Carolina Tafalla

tafalla@inia.es;

Aitor G. Granja

aitor.gonzalez@inia.es

Specialty section:

This article was submitted to

Cytokines and Soluble Mediators in

Immunity,

a section of the journal

Frontiers in Immunology

Received: 02 December 2016 Accepted: 01 March 2017

Published: 15 March 2017

Citation:

Tafalla C, González L, Castro R and Granja AG (2017) B Cell-Activating Factor Regulates Different Aspects of

$B$ Cell Functionality and Is Produced by a Subset of Splenic B Cells in

Teleost Fish.

Front. Immunol. 8:295. doi: 10.3389/fimmu.2017.00295
In mammals, B cell functionality is greatly influenced by cytokines released by innate cells, such as macrophages or dendritic cells, upon the early recognition of common pathogen patterns through invariant receptors. B cell-activating factor (BAFF) is one of these innate B cell-helper signals and plays a key role in the survival and differentiation of B cells. Although, evolutionarily, teleost fish constitute the first animal group in which adaptive immunity based on Ig receptors is present, fish still rely greatly on innate responses. In this context, we hypothesized that BAFF would play a key role in the control of $B$ cell responses in fish. Supporting this, our results show that teleost BAFF recapitulates mammalian BAFF stimulating actions on B cells, upregulating the expression of membrane $\mathrm{MHC} I \mathrm{I}$, improving the survival of fish naïve B cells and antibody-secreting cells, and increasing the secretion of IgM. Surprisingly, we also demonstrate that BAFF is not only produced in fish by myeloid cells but is also produced by a subset of splenic $\mathrm{B}$ cells. Thus, if this B cell-produced BAFF proves to be actively regulating this same $B$ cell subset, our findings point to an ancient mechanism to control B cell differentiation and survival in lower vertebrates, which has been silenced in mammals in physiological conditions, but reemerges under pathological conditions, such as B cell lymphomas and autoimmune diseases.

Keywords: teleost, B cells, B cell-activating factor, IgM, cell survival, MHC II

\section{INTRODUCTION}

In mammals, conventional B cells, also designated as follicular B cells or B2 cells, produce high affinity antibodies in response to specific epitopes through a somatically recombined B cell receptor (BCR) and, to fulfill this, they require the cooperation of $\mathrm{T}$ helper cells in germinal centers (GCs) within the lymphoid follicles. These T-dependent responses are quite effective, but temporally delayed, so T-independent (TI) B cell responses are also mounted immediately after pathogen recognition, to produce low-affinity poly specific antibodies, which offer fast protection, especially at the mucosal interfaces. Innate B cells such as B1 cells or marginal zone (MZ) B cells are mostly responsible for these TI responses $(1,2)$. Exemplifying further the crosstalk that exists between the adaptive and the innate immune system, B cells (both B2 and innate B cells) receive additional stimulatory signals from other cells of the innate immune system such as dendritic cells (DCs), macrophages, or granulocytes. These innate cells, upon sensing of conserved pathogen features through invariant pattern 
recognition receptors (PRRs), release $\mathrm{B}$ cell-stimulating factors $(3,4)$ that elicit extrafollicular TI responses (5) or complement the activity of T helper cells in GCs (6).

$\mathrm{B}$ cell-activating factor (BAFF) of the tumor necrosis factor (TNF) family (also known as BlyS, TALL-1, THANK, zTNF4, and TNFSF13B) and a proliferation-inducing ligand (APRIL), members of the TNF family, are two of the most important factors among these innate B cell-stimulating cytokines (7). Both of them are type II transmembrane proteins, which become soluble ligands after cleavage at the cell surface by a furin-like protease, with both the membrane-bound and soluble forms being biologically active (8). Concerning the receptors through which they signal, both BAFF and APRIL bind to B cell maturation antigen [(BCMA), also known as TNFRSF17] and transmembrane activator and calcium modulator and cyclophilin ligand interactor (TACI, also known as TNFRSF13B), whereas BAFF also binds to BAFF receptor (BAFF-R, also known as BR3 or TNFRSF13C) (7). All three receptors are preferentially expressed in $\mathrm{B}$ cells $(9,10)$.

In mammals, BAFF is not a stimulator of B cell proliferation on its own, but acts as a potent co-stimulator when combined with BCR engagement (11). On the other hand, BAFF is a strong promoter of B cell survival (12), mainly sustained through BAFF-R signaling (13). For this, BAFF-mediated NF- $\kappa B$ activation has been linked to increased expression of antiapoptotic proteins [reviewed in Ref. (14)]. On the other hand, TACI expression is highly inducible and has been shown to be particularly highly expressed in innate B1 cells (13) and consequently $\mathrm{TACI}^{-1-}$ animals are unable to mount normal TI immune responses (15), as the activation and survival of plasmablasts derived from innate B cells is compromised (16). Regarding BCMA, BAFF signaling through this receptor has been proven to be essential for the survival of long-lived plasma cells (17). BCMA can also promote the antigen-presenting function of $\mathrm{B}$ cells through upregulation of MHC II and co-stimulatory molecules (18), although BAFF-mediated upregulation of MHC class II expression is also achieved by signaling through TACI and BAFF-R (19).

The sequences of BAFF and APRIL have been previously identified in rainbow trout (Oncorhynchus mykiss) (20), along with that of a further fish-specific molecule with close homology to both BAFF and APRIL designated as BALM (BAFF- and APRIL-like molecule). In addition, BAFF sequences have been reported in different teleost fish species including zebrafish (Danio rerio) (21), mefugu (Takifugu obscurus) (22), Japanese sea perch (Lateolabrax japonicus) (23), grass carp (Ctenopharyngodon idella) (24), yellow grouper (Epinephelus awoara) (25), miiuy croaker (Miichthys miiuy) (26), tongue sole (Cynoglossus semilaevis) (27), Nile tilapia (Oreochromis niloticus) (28), rock bream (Oplegnathus fasciatus) (29), and cartilaginous fish such as white-spotted catshark (Chiloscyllium plagiosum) (30), spiny dogfish (Squalus acanthias) (31), and small-spotted catshark (Scyliorhinus canicula) (32). Although recombinant BAFF proteins have been produced for some of these species $(21-23,25,27-30)$, many of these studies have exclusively tested the effect of recombinant fish BAFF on B cell survival using mammalian B cells $(21,22,25,28,30)$. Furthermore, those studies, which have concluded a capacity of BAFF to induce proliferation using teleost leukocytes, have not made a distinction between proliferation and survival as they have only determined increased numbers of leukocytes after BAFF treatment and have not clearly established that the cells showing increased survival or proliferating were in fact B cells $(21-23,27,29)$. Consequently, the role that BAFF plays on B cell function in teleost remains largely unknown.

Although, evolutionarily, fish constitute the first group of animals in which all the key components of adaptive immunity are present, some unique structural features of the immune system predict important functional differences between fish and mammalian B cells. In teleost, the spleen constitutes the main secondary immune organ in the absence of lymph nodes. However, the splenic white pulp is poorly developed in comparison to mammals and no GCs are apparent (33). Additionally, fish contain only three immunoglobulin classes, namely IgM, IgD, and IgT (designated as IgZ in some species) (34). Since IgT is a teleost fish-specific Ig that seems to be specialized in mucosal immunity $(35,36)$ and $\operatorname{IgT}^{+} \mathrm{B}$ cells constitute a distinct linage (35), no class switch recombination has ever been reported in fish. Furthermore, teleost B cells share many features of mammalian B1 cells, as for example, long-term survival in cell culture, a high phagocytic capacity $(37,38)$, constitutive expression of many PRRs $(39,40)$, and expression of homolog molecules to B1-specific cell markers (41). As a result, the lack of teleost follicular structures and the conservation of many innate features of fish B cells strongly suggest that fish B cell responses best resemble mammalian TI responses.

In this context, it is of great interest to establish how innate $\mathrm{B}$ cell stimulating cytokines, such as BAFF, control B cells before the appearance of follicular structures and this is what we have addressed in the current study using rainbow trout as a model. Our findings show that, in teleost, as in mammals, BAFF has no effect on B cell proliferation but is exclusively a survival factor for splenic B cells. Interestingly, both splenic IgD ${ }^{+} \operatorname{IgM}^{+}$cells (exhibiting a naïve $\mathrm{B}$ cell phenotype) and $\operatorname{IgD}^{-} \operatorname{IgM}^{+}$cells (exhibiting a plasmablast phenotype) are expanded in the presence of BAFF and, consequently, IgM secretion is also augmented in these cultures. BAFF also increased the surface expression of MHC II in splenic B cells, but had no effect on their phagocytic capacity. Finally, we have established that, unlike the situation in mammals where BAFF is produced by cells of the innate immune system, a subpopulation of fish splenic B cells produce BAFF in physiological conditions, revealing an ancient mechanism to regulate B cell functionality in teleost. Throughout evolution, this capacity of B cells to produce BAFF has been lost, possibly upon the appearance of follicular structures that sustain B2 cell survival in physiological conditions, and only reappears in mammals during B cell proliferating disorders such as B cell lymphomas or autoimmune diseases.

\section{MATERIALS AND METHODS}

\section{Production of Recombinant Rainbow Trout BAFF}

The nucleotide sequence corresponding to the extracellular domain of the rainbow trout BAFF sequence (GenBank Accession number DQ218467.1) together with an N-terminal 6x histidine 
tag was synthetized and subcloned into the E3 expression vector (Abyntek). The recombinant plasmid was transformed into BL21 cells and a kanamycin-resistant single positive colony was then incubated at $37^{\circ} \mathrm{C}$ in Luria-Bertani media. When the $\mathrm{OD}_{600}$ reached $0.6,0.1 \mathrm{mM}$ of isopropyl $\beta$-D-thiogalactoside (IPTG, Sigma-Aldrich) was added to induce protein production. After $16 \mathrm{~h}$, cells were harvested, lysed by sonication, and dissolved using urea. Thereafter, BAFF was obtained through the use of Nickel columns (Sigma-Aldrich). The BAFF-containing fractions were pooled, refolded, filtered through $0.22 \mu \mathrm{m}$, and resuspended in storage buffer (50 mM Tris- $\mathrm{HCl}, 150 \mathrm{mM} \mathrm{NaCl}, 10 \%$ glycerol, $0.5 \mathrm{M}$ L-arginine, and $2 \mathrm{mM}$ DTT, $\mathrm{pH}$ 8.5). Protein concentration was determined in a BCA protein assay (Thermo Fisher Scientific) and the recombinant rainbow trout BAFF $(0.3 \mathrm{mg} / \mathrm{ml})$ was aliquoted and stored at $-80^{\circ} \mathrm{C}$ until used. An irrelevant protein with a similar molecular weight to that of recombinant BAFF (20.7 kDa), also bearing an N-terminal His tag was produced in the same conditions (C-His) and was used as a functional control.

\section{Generation of a Mouse pAb against Rainbow Trout BAFF}

Six-week-old BALBc mice were immunized with $60 \mu \mathrm{g}$ of recombinant BAFF protein emulsified in Montanide ISA 763 A VG adjuvant (Seppic) at a 1:1 ratio (volume). A $60 \mu \mathrm{g}$ booster shot emulsified in Montanide ISA 763 A VG was given at days 15 and 30 postimmunization. Mice were sacrificed 10 days after the last boost and peripheral blood was collected and serum obtained. The antibody was purified from the serum by immunoglobulin affinity using protein G-sepharose columns (Thermo Fisher Scientific), following manufacturer's instructions. Recombinant rainbow trout BAFF protein was used to test the specificity of the anti-BAFF polyclonal antibody against the pre-immune serum from the same animal, by Western blot. SDS-PAGE and Western blots were performed as previously described (42). For some applications, purified anti-BAFF antibody was biotinylated using EZ-link NHS Biotin (Thermo Fisher Scientific), following manufacturer's instructions. The protocol described for the generation of the polyclonal antibody described comply with the Guidelines of the European Union Council (2010/63/EU) for the use of laboratory animals and were previously approved by the Ethics committee from the Instituto Nacional de Investigación y Tecnología Agraria y Alimentaria (INIA; Code CEEA 2012/008).

\section{Experimental Fish}

Healthy specimens of female rainbow trout (O. mykiss) of approximately 50-70 g were obtained from Centro de Acuicultura El Molino (Madrid, Spain). Fish were maintained at the Animal Health Research Center (CISA-INIA) laboratory at $16^{\circ} \mathrm{C}$ with a re-circulating water system and 12:12-h light:dark photoperiod. Fish were fed twice a day with a commercial diet (Skretting, Spain). Prior to any experimental procedure, fish were acclimatized to laboratory conditions for 2 weeks and, during this period, no clinical signs were ever observed. The experiments described comply with the Guidelines of the European Union Council (2010/63/EU) for the use of laboratory animals and were previously approved by the Ethics committee from the Instituto
Nacional de Investigación y Tecnología Agraria y Alimentaria (INIA; Code CEEA 2011/044).

\section{Leukocyte Isolation}

Rainbow trout were killed by benzocaine (Sigma-Aldrich) overdose and blood was extracted with a heparinized needle from the caudal vein and diluted 10 times with Leibovitz medium (L-15, Invitrogen) supplemented with $100 \mathrm{IU} / \mathrm{ml}$ penicillin together with $100 \mu \mathrm{g} / \mathrm{ml}$ streptomycin (P/S, Life Technologies), $10 \mathrm{U} /$ $\mathrm{ml}$ heparin (Sigma-Aldrich), and 5\% fetal calf serum (FCS, Life Technologies). Spleen, head kidney, hindgut, skin, and peritoneal exudates were then collected. Single cell suspensions from spleen, head kidney, and peritoneum were obtained using $100 \mu \mathrm{m}$ nylon cell strainers (BD Biosciences). The hindgut samples were opened lengthwise, washed in phosphate-buffered saline (PBS), and cut into small pieces. The skin was cut off the fish with a scalpel, then, the muscle tissue was removed and the skin was further cleaned with ice-cold PBS and cut into small pieces. For hindgut and skin, the cell extraction procedure started with one round of 30 min agitation at $4^{\circ} \mathrm{C}$ in L-15 medium with P/S and 5\% FCS, followed by an agitation in PBS with $1 \mathrm{mM}$ EDTA and $1 \mathrm{mM}$ DTT for $30 \mathrm{~min}$. Finally, the tissues were digested with $0.15 \mathrm{mg} / \mathrm{ml}$ of collagenase (Sigma) in L- 15 for $1.5 \mathrm{~h}$ at $20^{\circ} \mathrm{C}$. All cell suspensions were placed onto 30/51\% discontinuous Percoll (GE Healthcare) density gradients and centrifuged at $500 \times g$ for $30 \mathrm{~min}$ at $4^{\circ} \mathrm{C}$. The interface cells were collected and washed twice in L-15 containing $5 \%$ FCS. When required, leukocytes were incubated in the presence of TNP-LPS (Biotools) at a final concentration of $5 \mu \mathrm{g} / \mathrm{ml}$ and/or recombinant rainbow trout BAFF at a final concentration of $3 \mu \mathrm{g} / \mathrm{ml}$. A wide range of doses of these stimuli were tested and the optimal doses were selected based on their effect on B cell survival (data not shown).

\section{Flow Cytometry}

The anti-trout IgD [ $\mathrm{mAb}$ mouse IgG $_{1}$ coupled to R-phycoerythrin

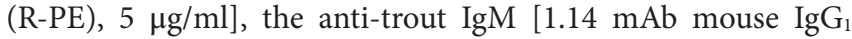
coupled to fluorescein (FITC) or to allophycocyanin (APC), $1 \mu \mathrm{g} / \mathrm{ml}$, and the anti-trout MHC II $\beta$-chain ( $\mathrm{mAb}$ mouse IgG $_{1}$ coupled to APC, $2 \mu \mathrm{g} / \mathrm{ml}$ ) used in this study have been previously characterized $(43,44)$. All the mAbs were fluorescently labeled using fluorescein, R-PE, or APC Lightning-Link labeling kits (InnovaBiosciences), following manufacturer's instructions. Spleen leukocytes were incubated with specific antibodies for $30 \mathrm{~min}$ in the case of anti-IgM or anti-MHC, or $45 \mathrm{~min}$ in the case of anti-IgD, washed three times with staining buffer (PBS containing $1 \%$ FCS and $0.5 \%$ sodium azide), and analyzed. A biotinylated version of anti-BAFF ( $\mathrm{pAb}$ mouse $\mathrm{IgG}, 1 \mu \mathrm{g} / \mathrm{ml}$ ) was used to determine endogenous BAFF expression by leukocytes. To carry this out, cells were incubated for $30 \mathrm{~min}$ with biotinylated anti-BAFF pAb, then washed three times with staining buffer, and incubated for another $30 \mathrm{~min}$ with streptavidin-FITC (Thermo Fisher Scientific). In all cases, isotype controls for mouse mAbs and anti-BAFF pAb (BD Biosciences) were tested in parallel to discard unspecific binding of the Abs. All the incubations were performed at $4^{\circ} \mathrm{C}$. After incubation with the corresponding stimuli, samples were incubated with $10 \mu \mathrm{g} / \mathrm{ml}$ propidium iodide (Thermo Fisher) for $5 \mathrm{~min}$ in the dark, and cell viability was 
analyzed in our experimental conditions $(n=3)$. All samples were analyzed on a FACSCalibur flow cytometer (BD Biosciences) equipped with CellQuest Pro software. Flow cytometry analysis was performed with FlowJo 10 (TreeStar).

\section{BAFF-Binding Assay}

For the analysis of BAFF binding to trout $\mathrm{B}$ cells, splenocytes were incubated for $1 \mathrm{~h}$ at $4^{\circ} \mathrm{C}$ with recombinant BAFF or C-His $(3 \mu \mathrm{g} /$ $\mathrm{ml}$ each) or with a stock of BAFF, which had been previously incubated with anti-BAFF pAb (protein:Ab molar ratio 1:10). After that, cells were washed with staining buffer and labeled with an FITC-anti-His mAb (Thermo Fisher Scientific) together with APC-anti-IgM mAb $(1 \mu \mathrm{g} / \mathrm{ml})$ for $30 \mathrm{~min}$ at $4^{\circ} \mathrm{C}$, then washed again, and analyzed by flow cytometry.

\section{Tissue Sampling for the Analysis of BAFF Transcription}

Rainbow trouts were killed by benzocaine overdose. Blood was extracted with a heparinized needle from the caudal vein. Spleen, head kidney, skin, heart, gills, thymus, hindgut, and liver were then collected and placed in Trizol (Thermo Fisher Scientific) after transcardial perfusion using teleost Ringer solution $\mathrm{pH}$ 7.4 with $0.1 \%$ procaine in order to remove all the circulating blood from the tissues $(39,45)$. Total RNA was extracted using a combination of Trizol and RNAeasy Mini kit (Qiagen) as previously described (43). RNA was also extracted from the RTS11 rainbow trout monocyte-macrophage cell line (46) and the RTG2 fibroblast cell line (ATCC CCL-55) following the same procedure. The expression of individual genes was normalized to relative expression of trout EF- $1 \alpha$ and the expression levels were calculated using the $2^{-\Delta \mathrm{Ct}}$ method, where $\Delta \mathrm{Ct}$ is determined by subtracting the EF- $1 \alpha$ value from $\mathrm{Ct}$ of the targeted gene as previously described (43). RNA pellets were eluted from the columns in RNase-free water, quantified in a Nanodrop 1000 spectrophotometer (Thermo Scientific), and stored at $-80^{\circ} \mathrm{C}$ until used. RNAs were treated with DNase during the purification process to remove genomic DNA that might interfere with the PCR reactions and then used to obtain cDNA in each sample using the Bioscript reverse transcriptase (Bioline Reagents Ltd.) and oligo $(\mathrm{dT})_{12-18}(0.5 \mu \mathrm{g} / \mathrm{ml})$ following manufacturer's instructions. Minus reverse transcriptase controls were included in all the assays to rule out amplification of genomic DNA. The resulting cDNA was diluted 1:5 in DNAse-free water and stored at $-20^{\circ} \mathrm{C}$. Transcription levels were analyzed by real-time PCR with a LightCycler ${ }^{\circledR} 96$ System (Roche) using FastStart Essential DNA Green Master reagents (Roche) and specific primers (Table S1 in Supplementary Material). Each sample was measured under the following conditions: $10 \mathrm{~min}$ at $95^{\circ} \mathrm{C}$, followed by 40 amplification cycles $\left(10 \mathrm{~s}\right.$ at $95^{\circ} \mathrm{C}, 10 \mathrm{~s}$ at $60^{\circ} \mathrm{C}$, and $10 \mathrm{~s}$ at $\left.72^{\circ} \mathrm{C}\right)$. The expression of individual genes was normalized to relative expression of trout EF- $1 \alpha$ and the expression levels were calculated using the $2^{-\Delta \mathrm{Ct}}$ method, where $\Delta \mathrm{Ct}$ is determined by subtracting the EF- $1 \alpha$ value from $\mathrm{Ct}$ of the targeted gene as previously described (43). Negative controls with no template were included in all the experiments. A melting curve for each PCR was determined by reading fluorescence every degree between 60 and $95^{\circ} \mathrm{C}$ to ensure that only a single product had been amplified.

\section{Gene Expression Analysis in FACS- Isolated Populations}

To analyze BAFF transcription levels, $\operatorname{IgM}^{+} \mathrm{B}$ cells were isolated from spleen, head kidney, blood, and peritoneum. To carry this out, cells were FACS isolated with specific mAbs against IgM, as previously described (39). $\mathrm{CD}^{+} \mathrm{T}$ cells $\left(\mathrm{CD} 8^{+} \mathrm{MHC} \mathrm{II}^{-}\right.$cells) were isolated from spleen, and $\mathrm{CD}^{+} \mathrm{DCs}$ (myeloid $\mathrm{CD} 8^{+} \mathrm{MHC}$ $\mathrm{II}^{+}$) were obtained from skin using specific $\mathrm{mAbs}$ against CD8 and MHC II, as previously described (44). To analyze the gene expression pattern of B cell subsets from the spleen, splenocytes were stained using $\mathrm{mAbs}$ against $\operatorname{IgD}$ and $\operatorname{IgM}$, as described above, and $\mathrm{IgD}^{+} \operatorname{IgM}^{+}$and $\operatorname{IgD}^{-} \operatorname{IgM}^{+} \mathrm{B}$ cells were FACS isolated. To analyze the transcriptional levels of MHC II and Blimp-1 on BAFF-treated B cells, splenocytes were stained using a mAb against $\operatorname{IgM}$, as described above, and $\operatorname{IgM}^{+} \mathrm{B}$ cells were FACS isolated. In all cases, FACS isolation was performed using a BD FACSAria III (BD Biosciences). We analyzed the purity of the isolated populations by flow cytometry after sorting and only those samples showing a purity level higher than 95\% were used for qPCR analysis. RNA isolation and expression of individual genes was performed as previously described (44). Briefly, total RNA from FACS-isolated cells was isolated using the Power SYBR Green Cells-to-Ct Kit (Thermo Fisher Scientific) following manufacturer's instructions. RNAs were treated with DNase during the process to remove genomic DNA that might interfere with the PCR reactions. Reverse transcription was also performed using the Power SYBR Green Cells-to-Ct Kit according to manufacturer's instructions. Minus reverse transcriptase controls were included in all the assays to rule out amplification of genomic DNA. To evaluate the levels of transcription of BAFF in these samples, real-time PCR was performed with a LightCycler ${ }^{\circledR} 96$ System instrument using SYBR Green PCR core Reagents (Applied Biosystems) and specific primers (Table S1 in Supplementary Material). Each sample was measured in duplicate under the following conditions: $10 \mathrm{~min}$ at $95^{\circ} \mathrm{C}$, followed by 45 amplification cycles $(15 \mathrm{~s}$ at $95^{\circ} \mathrm{C}$ and $1 \mathrm{~min}$ at $60^{\circ} \mathrm{C}$ ). A melting curve for each PCR was also included to ensure only a single product had been amplified. The expression of individual genes was normalized to the relative expression of trout housekeeping gene EF- $1 \alpha$ elongation factor as described above.

\section{Phagocytic Activity}

For the analysis of phagocytosis, spleen leukocytes were seeded in 24-well plates (Nunc) at a cell density of $1 \times 10^{6}$ cells per well and incubated for $24 \mathrm{~h}$ at $20^{\circ} \mathrm{C}$ with BAFF $(3 \mu \mathrm{g} / \mathrm{ml})$, TNP-LPS $(5 \mu \mathrm{g} / \mathrm{ml})$, a combination of both, or left unstimulated (control), and then incubated for another $16 \mathrm{~h}$ at $20^{\circ} \mathrm{C}$ with fluorescent polystyrene-based particles (FluoSpheres ${ }^{\circledR}$ Microspheres, $1.0 \mu \mathrm{m}$, Crimson Red Fluorescent 625/645, 2\% solids; Life Technologies) at a cell:bead ratio of 1:10 or without beads as negative controls. Cells were harvested using a standard cell scraper (Corning). Non-ingested beads were removed by centrifugation $(100 \times g$ for $10 \mathrm{~min}$ at $4^{\circ} \mathrm{C}$ ) over a cushion of $3 \%$ (weight/volume) bovine serum albumin [(BSA), Fisher Scientific] in PBS supplemented with $4.5 \%$ (weight/volume) D-glucose (Sigma). Cells were resuspended in staining buffer, labeled with an anti-IgM mAb fluorescently labeled with FITC, and analyzed on a FACSCalibur flow 
cytometer equipped with CellQuest sofware (BD Biosciences). The analysis was also performed with FlowJo 10.

\section{B Cell Proliferation}

The BrdU Flow Kit (Becton Dickinson) was used to measure the proliferation of $\operatorname{IgM}^{+} \mathrm{B}$ cells in response to BAFF and/or TNP-LPS following manufacturer's instructions. Splenocytes at a concentration of $2 \times 10^{6}$ cells $/ \mathrm{ml}$ were incubated for 3 days at $20^{\circ} \mathrm{C}$ with the stimuli as described above. Bromodeoxyuridine (BrdU, $10 \mu \mathrm{M}$ ) was then added to the cultures and the cells were incubated for an additional $24 \mathrm{~h}$. The cells were collected and stained with APC-anti-IgM mAb $(1 \mu \mathrm{g} / \mathrm{ml})$. Briefly, to analyze incorporation of BrdU, cells were then fixed and permeabilized with Cytofix/Cytoperm Buffer for 15 min on ice, then incubated with Cytoperm Permeabilization Buffer Plus for 10 min on ice, and re-fixed with Cytofix/Cytoperm Buffer for $5 \mathrm{~min}$ at RT. Cells were then incubated with DNase $\left(30 \mu \mathrm{g} / 10^{6}\right.$ cells) for $1 \mathrm{~h}$ at $37^{\circ} \mathrm{C}$ to expose the incorporated BrdU. Finally, cells were stained with FITC anti-BrdU antibody for $20 \mathrm{~min}$ at RT and analyzed by flow cytometry.

\section{Confocal Microscopy}

Splenocytes were obtained as described above. To establish BAFF binding to trout $\operatorname{IgM}^{+} \mathrm{B}$ cells, leukocytes were incubated with $3 \mu \mathrm{g} / \mathrm{ml}$ of recombinant BAFF in L-15 media supplemented with $5 \%$ FCS. After $1 \mathrm{~h}$ at $20^{\circ} \mathrm{C}$, the cells were washed with serumfree L-15 medium, seeded on poly L-lysine coated slides, and incubated at $20^{\circ} \mathrm{C}$ for $30 \mathrm{~min}$. After gently washing with PBS, the slides were fixed in 4\% PFA for $15 \mathrm{~min}$ at RT. The samples were permeabilized for $1 \mathrm{~h}$ at RT with permeabilizing solution (TBS buffer, $\mathrm{pH}=7.5$, containing $0.01 \%$ BSA, $0.02 \%$ Tween20 , and $0.5 \%$ saponin) and then incubated for $1 \mathrm{~h}$ at RT with blocking solution (TBS buffer, $\mathrm{pH}=7.5$, containing $0.01 \% \mathrm{BSA}$, $0.02 \%$ Tween-20, $0.5 \%$ saponin, and $10 \%$ rabbit and goat serum). Fixed cell slides were then incubated with APC-anti-IgM mAb $(1 \mu \mathrm{g} / \mathrm{ml})$ and an FITC-anti-His mAb for $30 \mathrm{~min}$. Samples were counterstained with $1 \mu \mathrm{g} / \mathrm{ml}$ DAPI (Sigma).

To analyze BAFF production by $\operatorname{IgM}^{+} \mathrm{B}$ cells, leukocytes were suspended in serum-free L-15 medium, seeded on poly L-lysine coated slides, and incubated at $20^{\circ} \mathrm{C}$ for $30 \mathrm{~min}$. After gently washing with PBS, the slides were fixed, permeabilized, and washed as described above. Fixed cell slides were then incubated with antiBAFF pAb coupled to biotin for $30 \mathrm{~min}$, then gently washed, and incubated with APC-anti-IgM $(1 \mu \mathrm{g} / \mathrm{ml})$ and streptavidin-FITC (Thermo Fisher Scientific) for $30 \mathrm{~min}$. Samples were counterstained with $1 \mu \mathrm{g} / \mathrm{ml}$ DAPI (Sigma). In all cases, laser scanning confocal microscopy images $(0.3 \mu \mathrm{m}$ thickness) were acquired with an inverted Zeiss Axiovert LSM 880 microscope. Images were analyzed with Zen 2.0 (Carl Zeiss) and Fiji (NIH) software packages.

\section{ELISPOT Analysis}

ELISPOT was used to quantify the number of IgM-secreting B cells. Splenocytes were incubated with BAFF $(3 \mu \mathrm{g} / \mathrm{ml})$, and/ or TNP-LPS $(5 \mu \mathrm{g} / \mathrm{ml})$, or left unstimulated (control) at $20^{\circ} \mathrm{C}$ for $48 \mathrm{~h}$. ELISPOT plates containing Inmobilon-P membranes (Millipore) were activated with $70 \%$ ethanol for $30 \mathrm{~s}$, coated with anti-trout $\operatorname{IgM} \mathrm{mAb}$ (clone $4 \mathrm{C} 10$ ) at $2 \mu \mathrm{g} / \mathrm{ml}$ in PBS, and incubated overnight at $4^{\circ} \mathrm{C}$. To block non-specific binding to the membrane, plates were then incubated with $2 \%$ BSA in PBS for $2 \mathrm{~h}$ at RT. Thereafter, leukocytes from individual fish were added to the wells in triplicate at a concentration of $1 \times 10^{5}$ cells per well. After $24 \mathrm{~h}$ of incubation at $20^{\circ} \mathrm{C}$, cells were washed away five times with PBS and plates were blocked again with $2 \%$ BSA in PBS for $1 \mathrm{~h}$ at RT. After blocking, biotinylated anti-trout IgM $\mathrm{mAb}$ (clone $4 \mathrm{C} 10$ ) was added to the plates and incubated at $1 \mu \mathrm{g} /$ $\mathrm{ml}$ for $1 \mathrm{~h}$ at RT. Following additional washing steps (five times in $\mathrm{PBS}$ ), the plates were developed using streptavidin-HRP (Thermo Scientific) at RT for $1 \mathrm{~h}$, washed again with PBS, and incubated with 3-amino 9-ethylcarbazole (Sigma-Aldrich) for $30 \mathrm{~min}$ at RT in the dark. Substrate reaction was stopped by washing the plates with tap water. Once the membranes had dried, they were digitally scanned and spot counts determined by the ImmunoSpot Series 45 Micro ELISPOT Analyzer.

\section{Statistical Analysis}

Statistical analyses were performed conducting one-way ANOVA to analyze whether significant differences exist between the means of all the experimental groups included in each assay. When significant differences were found, we then performed a post hoc multiple comparison Tukey's test. The differences between the mean values were considered significant on different degrees, where ${ }^{\star} p \leq 0.05,{ }^{* *} p \leq 0.01$, and ${ }^{* *} p \leq 0.005$. The analysis was performed with XLSTAT statistical software for Excel (Microsoft) and GraphPad Prism 6 software (GraphPad).

\section{RESULTS}

\section{Recombinant BAFF Binds Teleost B Cells}

The soluble domain of rainbow trout BAFF was produced in $E$. coli, purified under denaturing conditions, and refolded in vitro (Figure S1A in Supplementary Material). To confirm that LPS contamination in the recombinant protein was negligible, we verified that recombinant BAFF had no effects on the expression of IL-1 $\beta$ on splenocytes, since this gene has been shown to be highly upregulated by bacterial LPS in this system $(47,48)$ (Figure S1B in Supplementary Material).

Next, we verified that splenic $\operatorname{IgM}^{+}$B cells were able to bind recombinant BAFF. For this, we incubated total leukocytes from the spleen of unstimulated fish with recombinant histidinetagged BAFF for $1 \mathrm{~h}$, then labeled the cells with an anti-IgM $\mathrm{mAb}$ and an anti-His $\mathrm{mAb}$, and performed flow cytometry analysis. We verified that an average $6.5 \%$ of the splenic lymphocytes-bound recombinant BAFF and more than half of these cells were $\operatorname{IgM}^{+}$ B cells (Figures 1A,B). These BAFF-binding IgM $^{+}$B cells correspond to an average $8.4 \%$ of the $\operatorname{IgM}^{+} \mathrm{B}$ cell population, whereas only $3.9 \%$ of the $\mathrm{IgM}^{-} \mathrm{B}$ cells were binding the recombinant cytokine (Figure 1C). To confirm that BAFF binding to B cells was specific, we blocked the union with a polyclonal antibody raised against recombinant trout BAFF in mice. This polyclonal antibody was highly specific and recognized recombinant BAFF protein in Western blot (Figure S2A in Supplementary Material) and also membrane BAFF present on spleen lymphocytes by 


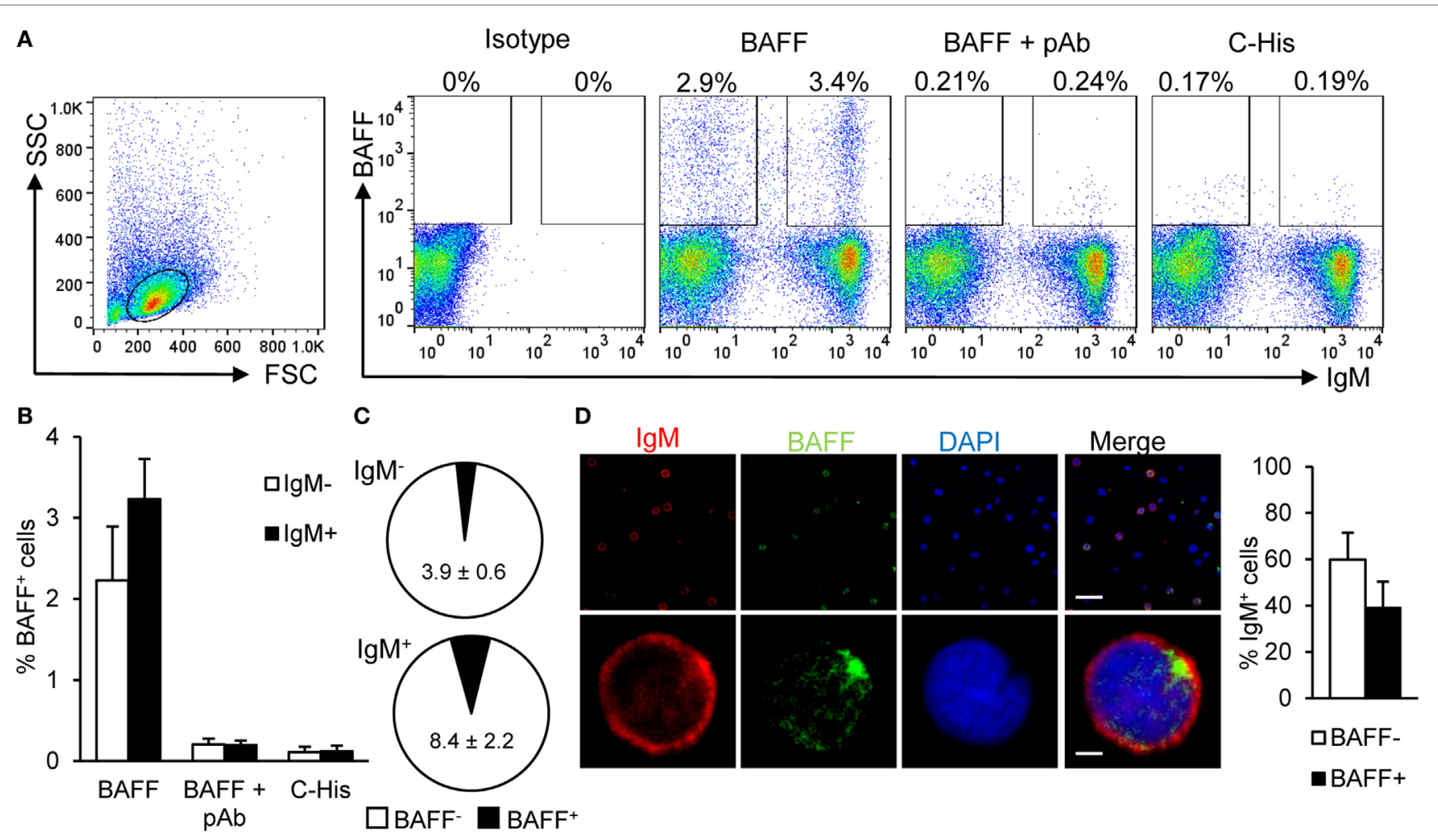

FIGURE 1 | Rainbow trout B cell-activating factor (BAFF) binds to IgM+ $\mathbf{M}^{+}$cells. To analyze the specific binding of BAFF to lgM+ $\mathrm{B}$ cells, freshly isolated splenic leukocytes were incubated with recombinant histidine-tagged BAFF protein ( $3 \mu \mathrm{g} / \mathrm{ml})$ or an irrelevant $20 \mathrm{kDA}$ histidine-tagged protein (C-His, $3 \mu \mathrm{g} / \mathrm{ml})$ for $1 \mathrm{~h}$. In parallel, cells were also cultured for $1 \mathrm{~h}$ with recombinant BAFF protein, which had been previously incubated for $1 \mathrm{~h}$ with an anti-BAFF pAb (molar ratio 1:10). Thereafter, cells were stained with an anti-lgM mAb together with an anti-His mAb, or with isotype control mAbs, and analyzed by flow cytometry. Dot plots from one representative experiment are shown (A) and percentages of BAFF-binding IgM $^{-}$and $\operatorname{lgM}^{+}$cells are indicated in the plots. The quantification of BAFF binding on $\mathrm{IgM}^{-}$and $\mathrm{IgM}^{+} \mathrm{B}$ cells is also shown (B) as mean $+\mathrm{SD}(n=9$, three experiments containing three animals each). (C) The percentages of cells binding BAFF within the $\mathrm{lgM}^{-}$and $\mathrm{lgM}^{+}$compartments were also calculated and are plotted as pie charts (mean $\pm \mathrm{SD}, n=9$, three independent experiments containing three animals each). Dead cells were not excluded during the flow cytometry analysis, but cell viability was higher than $99 \%$ for lgM+ B cells and higher than $95 \%$ for other lymphocytes on these experimental settings (Figure S4A in Supplementary Material). (D) Total leukocytes from spleen were incubated with recombinant BAFF (3 $\mu$ g/ $\mathrm{ml}$ ) for $1 \mathrm{~h}$, then plated onto poly-L-lysine-coated glass slides, fixed and labeled with anti-lgM (shown as red) and anti-His (BAFF, shown as green) antibodies, then counterstained with DAPI (blue), and analyzed by fluorescence microscopy. A representative general overview is shown (upper row) (scale bar, $20 \mu \mathrm{m}$ ) and the amplification detail of a single cell (lower row) (scale bar, $1 \mu \mathrm{m}$ ). IgM+BAFF- and lgM+BAFF+ cells on preparations of spleen leukocytes from eight fish were quantified and plotted (right bar plot) and shown as mean + SD $(n=150$ cells).

flow cytometry (Figure S2B in Supplementary Material). In the splenocyte BAFF-binding assays, when recombinant BAFF was incubated with the polyclonal anti-BAFF before its addition to splenocytes, its binding decreased to nearly undetectable levels, both in $\mathrm{IgM}^{+}$and $\mathrm{IgM}^{-}$populations (Figures $1 \mathbf{A}, \mathbf{B}$ ), demonstrating the specificity of the binding and that of the polyclonal antibody. To rule out a possible binding of BAFF through the histidine tag in an unspecific fashion, we incubated splenocytes with an irrelevant protein of the same molecular weight carrying a histidine tag, and as shown in Figures 1A,B, only a negligible binding was observed. An additional control was included to exclude the possibility of the anti-BAFF pAb blocking the access of the anti-His mAb to the His tag instead of BAFF binding to the cells, we incubated spleen leukocytes with BAFF for $1 \mathrm{~h}$, and then incubated these cells with anti-BAFF pAb for $1 \mathrm{~h}$. In this case, we did not see any difference on BAFF binding, thus demonstrating that the pAb anti-BAFF blocks the binding of BAFF to the cells but does not interfere with the access of the anti-His to the His tag once BAFF is bound to the cells (Figure S3 in Supplementary Material). To visualize BAFF binding to $\operatorname{IgM}^{+} \mathrm{B}$ cells, we incubated total leukocytes from the spleen of unstimulated fish with recombinant histidine-tagged BAFF for $1 \mathrm{~h}$, and then fixed the cells to analyze them through confocal microscopy. We further verified that spleen $\operatorname{IgM}^{+}$B cells co-stained with recombinant $\mathrm{BAFF}$ (Figure 1D). In this case, the average number of $\mathrm{BAFF}^{+}$cells observed within the $\operatorname{IgM}^{+}$compartment was $39.2 \%$, which was higher than that seen for extracellular binding analyzed by flow cytometry. The reason for this difference is that, through confocal microscopy, we are able to observe both extracellular (binding) and intracellular (internalization) staining, however, we cannot exclude that part of the internalization of BAFF is due to receptorindependent mechanisms such as pinocytosis. All together, these results unequivocally demonstrate that a subpopulation of trout splenic B cells is able to bind to soluble BAFF. 


\section{Spleen B Cells Express BAFF Constitutively in Teleost}

Prior to the determination of BAFF functionality in trout B cells, we conducted a series of experiments to study, which cell types were producing BAFF in physiological conditions. First, we analyzed the transcription of BAFF throughout the different tissues in unstimulated rainbow trout. BAFF mRNA levels were higher in the spleen, followed by other immune tissues such as peripheral blood and the head kidney (the main hematopoietic organ in fish) (Figure 2A). Intermediate BAFF transcript levels were observed in skin, heart, gills, thymus, and gut, while very low transcript levels were found in the liver (Figure 2A). BAFF transcription was then examined in different immune cell subsets. As expected, CD8 ${ }^{+}$DCs from skin expressed high levels of BAFF (Figure 2B), but to our surprise, these levels were comparable to those observed in $\operatorname{IgM}^{+} \mathrm{B}$ cells from spleen, head kidney, and blood (Figure 2B). Intermediate BAFF expression levels were found in $\operatorname{IgM}^{+} \mathrm{B}$ cells from other peripheral tissues, such as the peritoneal cavity or the hindgut. On the other hand, $\mathrm{CD}^{+} \mathrm{T}$ cells from the spleen contained low amounts of BAFF mRNA, while no BAFF transcription was observed in the RTS11 monocyte-macrophage or the RTG2 fibroblast cell lines (Figure 2B).

Because mammalian unstimulated B cells do not express BAFF to confirm the transcriptomic results that suggested that teleost naïve $B$ cells produce this cytokine, we studied the presence of BAFF in spleen $\operatorname{IgM}^{+}$cells through flow cytometry using the anti-BAFF polyclonal antibody developed. Approximately $14 \%$ of the cells within the myeloid gate (large size and high complexity) were producing BAFF, which could indicate BAFF production by DCs and macrophages (Figures 2C,D). Within the lymphoid gate, we studied BAFF production in $\operatorname{IgM}^{+}$and $\mathrm{IgM}^{-}$cell populations, verifying that a fraction of $\operatorname{IgM}^{+} \mathrm{B}$ cells express endogenous BAFF on the cell surface (Figures 2C,D). In average, almost $7 \%$ of the splenic $\operatorname{IgM}^{+}$B cells produced BAFF, whereas only around $3.7 \%$ of the $\operatorname{IgM}^{-}$lymphocytes produced the cytokine (Figures 2C,D). These results reveal that within the BAFF-producing leukocyte compartment, although the majority of the cells producing BAFF were myeloid cells (55.4 $\pm 19.9 \%)$, $28.1 \pm 4.9 \%$ of the BAFF-producing cells among splenocytes were $\mathrm{IgM}^{+} \mathrm{B}$ cells (Figure 2F). Furthermore, the levels of membrane BAFF seen in $\mathrm{IgM}^{+} \mathrm{B}$ cells, estimated by the mean fluorescence intensity (MFI) values, were equivalent to those found in myeloid cells and were much higher than those seen in $\operatorname{IgM}^{-}$leukocytes (Figure 2E). When the anti-BAFF pAb was premixed with recombinant BAFF, we did not observe any binding of the antibody to either lymphoid or myeloid cells, thus confirming that we were observing a specific staining for membrane BAFF (Figure S2C in Supplementary Material). In order to visualize $\mathrm{IgM}^{+} \mathrm{B}$ cells-expressing BAFF, splenocytes were fixed and labeled with anti-IgM and anti-BAFF antibodies and analyzed by laser scanning confocal microscopy. We observed that $\operatorname{IgM}^{+} \mathrm{B}$ cells from non-stimulated animals exhibited a positive staining for BAFF (Figure 2G) in a proportion similar to that seen by flow cytometry. These results demonstrate that teleost spleen B cells differ from mammalian B cells in their capacity to produce BAFF in physiological conditions.

\section{BAFF Upregulates Membrane MHC-II Expression on B Cells without Altering Their Antigen Acquisition Capacities through Phagocytosis}

We studied whether BAFF could have an effect on the levels of surface MHC-II expression using a specific anti-trout MHC II antibody (44). Our results showed that, after incubation with BAFF, membrane MHC II levels increased over time on $\operatorname{IgM}^{+}$ $B$ cells reaching a significantly increased peak of expression at $72 \mathrm{~h}$ (Figures 3A,B). We compared our results to those elicited by TNP-LPS, given the fact that LPS is a highly effective polyclonal activator of B cells from many species. Although TNP-LPS also upregulated MHC II surface expression, the levels induced by BAFF were significantly higher than those elicited by TNP-LPS and no synergies between TNP-LPS and BAFF were observed (Figure 3A). The increase of membrane MHC II expression was clear in cell cultures from all fish examined individually (Figure 3B) and was not observed when a histidine-tagged irrelevant protein with a similar molecular weight was used (Figure S5A in Supplementary Material).

To assess whether the increase on membrane MHC II level was a consequence of increased gene transcription, we analyzed MHC II transcription levels in sorted $\operatorname{IgM}^{+} \mathrm{B}$ cells treated or not with recombinant BAFF for 24,48 , and $72 \mathrm{~h}$. We found that MHC II mRNA levels were not upregulated by BAFF in sorted B cells at any time point analyzed (Figure 3C), suggesting that the effect of BAFF could be based on translocation of MHC II molecules to the plasma membrane or an increase of the half-life of membrane MHC II due to a potential activation of B cells (49).

Since rainbow trout $B$ cells have been shown to have potent phagocytic capacities (37), and this peculiar trait strongly conditions its antigen-presenting abilities, we aimed to study whether BAFF could also affect the phagocytic capacity of $\operatorname{IgM}^{+} B$ cells. In this occasion, we observed that BAFF did not alter the average percentage of phagocytic IgM+ $\mathrm{B}$ cells. TNP-LPS or a combination of BAFF with TNP-LPS did not affect the number of phagocytic $\operatorname{IgM}^{+} \mathrm{B}$ cells either (Figures 3D,F). In parallel, the MFI of beads ingested by the $\operatorname{IgM}^{+} \mathrm{B}$ cells was not affected by any of the stimuli tested (Figures 3E,F). Thus, our results suggest a role for BAFF in the regulation of $\mathrm{B}$ cell antigen presentation, through increased surface MHC II levels but without affecting antigen acquisition by phagocytosis.

\section{BAFF Has No Proliferative Effects of Trout B Cells}

A few studies in fish have concluded a capacity of BAFF to induce proliferation of total leukocyte populations using methodological approaches that do not make a distinction between proliferation and survival $(22,23,27,29)$. Thus, in this study, we wanted to clearly address this issue and clarify whether fish BAFF has proliferative effects or, as in mammals, it is exclusively a survival factor. When the proliferative effects of BAFF were tested on $\operatorname{IgM}^{+} \mathrm{B}$ cells from spleen by means of BrdU incorporation, we verified that BAFF is incapable of inducing proliferation of $\operatorname{IgM}^{+} \mathrm{B}$ cells, with almost undetectable proliferation rates that were significantly lower than those elicited by TNP-LPS (Figures 4A,B). When TNP-LPS was 


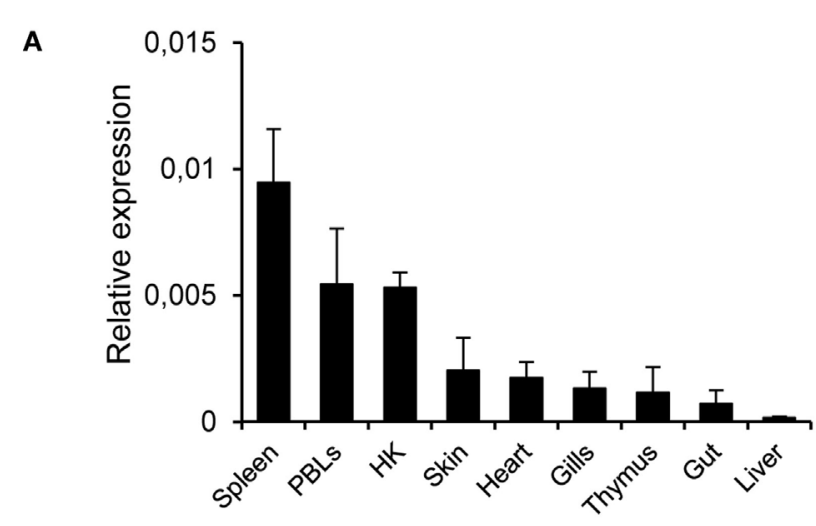

B

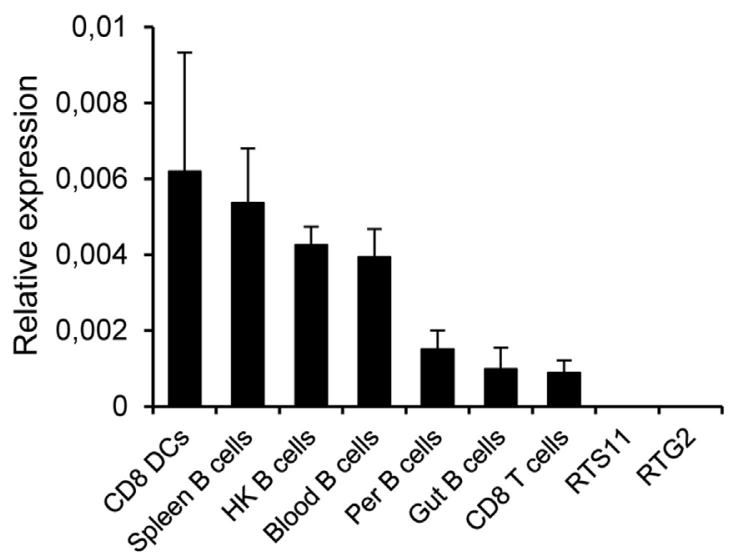

C

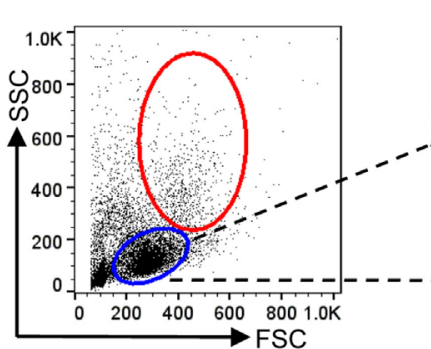

D

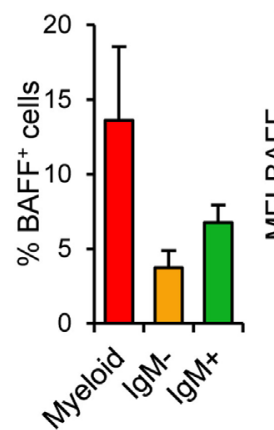

E

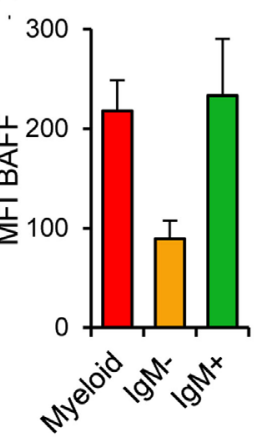

Lymphoid

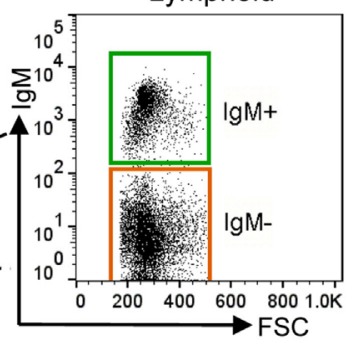

$\mathbf{F}$

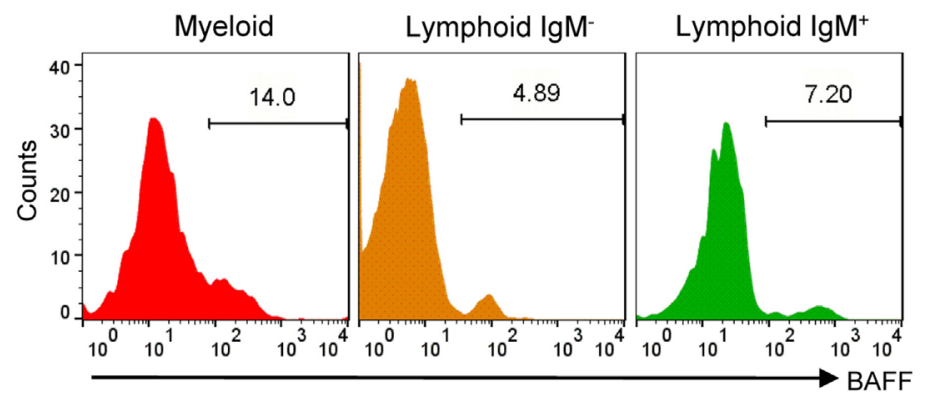

G

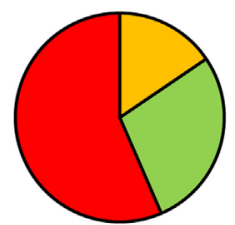

Myeloid: $55.4 \pm 19.9$

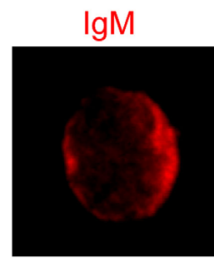

BAFF

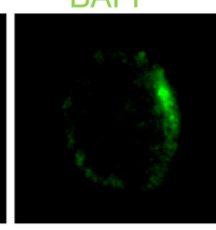

DAPI

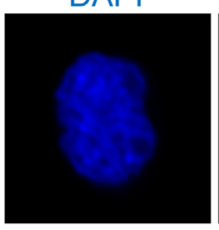

$\square \lg \mathrm{M}$-: $15.5 \pm 4.7$

$\lg M+: 28.1 \pm 4.9$

FIGURE 2 | B cell-activating factor (BAFF) expression in rainbow trout in physiological conditions. BAFF transcription levels were analyzed through real-time PCR in rainbow trout tissues (A) and FACS isolated cell subsets and in the RTS11 (macrophages) and RTG2 (fibroblasts) cell lines (B) the relative expression to the endogenous control EF-1 $\alpha$ was calculated for each sample (shown as mean + SD, $n=6)(H K$, head kidney; DCs, dendritic cells; Per, peritoneum). (C) Rainbow trout leukocytes isolated from spleen were stained with an anti-lgM mAb together with an anti-BAFF pAb and analyzed by flow cytometry. Lymphoid

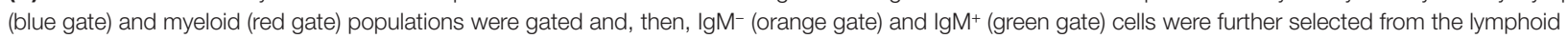
population. A representative histogram showing the level of BAFF expression in each population is shown. The average percentage of BAFF+ cells within each compartment was also calculated (D) as well as the mean fluorescence intensity of BAFF on those populations (E) (shown as mean + SD, $n=9$, three independent experiments containing three animals each). (F) The percentages of myeloid, lymphoid lgM ${ }^{-}$, and lymphoid lgM ${ }^{+}$cells within the BAFF ${ }^{+}$compartment were also calculated and are plotted as pie charts (mean $\pm \mathrm{SD}, n=9$, three independent experiments containing three animals each). Dead cells were not excluded during the flow cytometry analysis, but cell viability was higher than $99 \%$ for lgM+ B cells and higher than $95 \%$ for other lymphocytes on these experimental settings (Figure S4B in Supplementary Material). (G) Total leukocytes from spleen were plated onto poly-L-lysine-coated glass slides, fixed and labeled with anti-lgM (red) and anti-BAFF (green) antibodies, then counterstained with DAPI (blue), and analyzed by fluorescence microscopy. Images from one representative experiment are shown (scale bar, $1 \mu \mathrm{m})$.

combined with BAFF, the TNP-LPS-elicited proliferation was not further affected (Figures 4A,B), revealing that BAFF does not even have a synergistic effect on the $B$ cell proliferation induced by TNP-LPS. In a similar way, but a lower extent, TNP-LPS was also able to induce the proliferation of an $\mathrm{IgM}^{-}$lymphocyte population, but this population did not proliferate in response to BAFF either (Figures 4A,B).

\section{BAFF Is a Survival Factor for Trout IgM+ B Cells}

Despite the negligible proliferative effects, BAFF significantly increased the survival of $\operatorname{IgM}^{+} \mathrm{B}$ cells compared to control cultures, determined as the percentage of $\operatorname{IgM}^{+}$cells in culture after 3 days, at levels comparable to those induced by TNP-LPS

(Figures 5A,C). This increased survival was very consistent and 

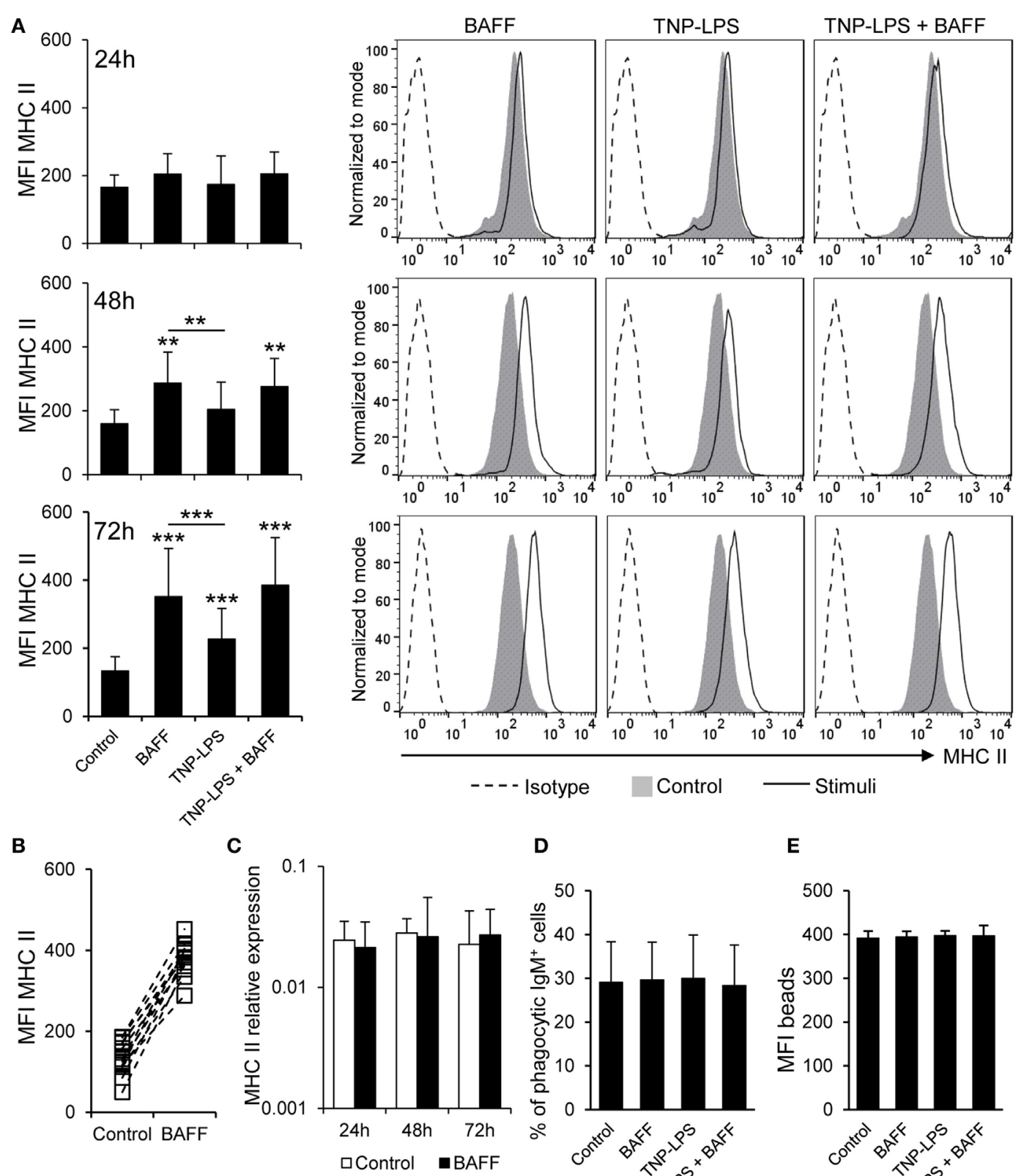

D

E
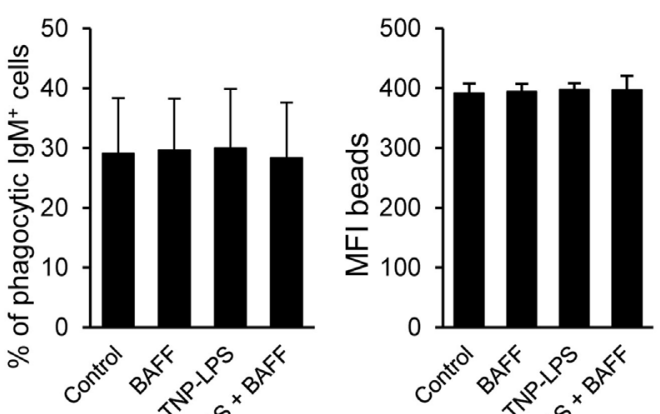

F

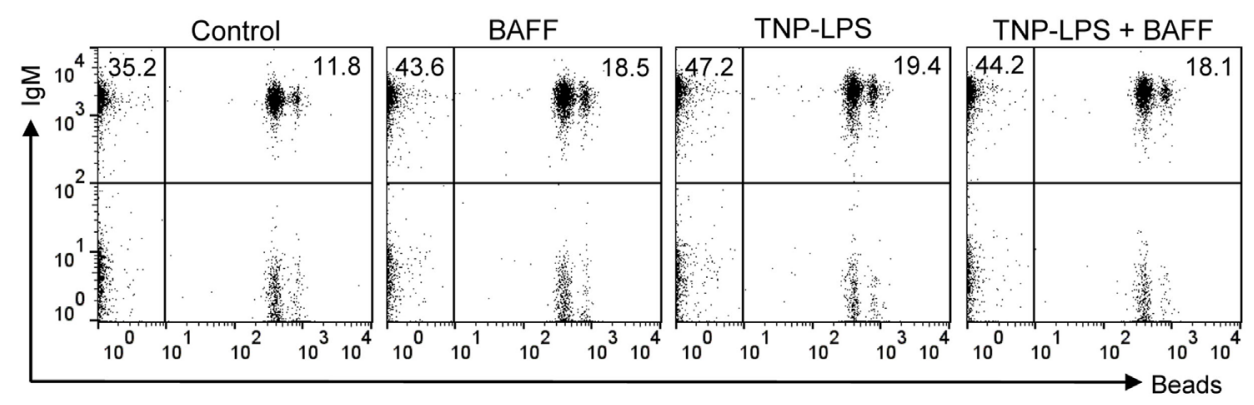

FIGURE 3 | Continued 


\section{FIGURE 3 | Continued}

B cell-activating factor (BAFF) increases the expression of membrane MHC II without altering antigen acquisition by phagocytosis. (A) Spleen leukocytes were incubated with BAFF $(3 \mu \mathrm{g} / \mathrm{ml})$, TNP-LPS $(5 \mu \mathrm{g} / \mathrm{ml})$, a combination of both, or left unstimulated (control) for 24,48 , or $72 \mathrm{~h}$ at $20^{\circ} \mathrm{C}$. After this time, cells were labeled with anti-IgM and anti-MHC II mAbs and analyzed by flow cytometry. Mean fluorescence intensity (MFI) for membrane MHC II was measured on $\mathrm{IgM}^{+} \mathrm{B}$ cells and average values were plotted as mean $+\mathrm{SD}$ (left) ( $n=12$ from four independent experiments containing three animals each). Histograms from one representative experiment, showing $\mathrm{MHC} \| \mathrm{MFI}$ on IgM+ gated B cells are shown (right panels). (B) The MFI of MHC II for each individual fish under control or BAFF stimulation conditions for $72 \mathrm{~h}$ is also plotted. (C) Splenocyte cultures were treated with BAFF ( $3 \mu \mathrm{g} / \mathrm{ml})$ or left unstimulated (control) for 24 , 48 , and $72 \mathrm{~h}$, and then, RNA was extracted from IgM+ FACS isolated B cells, as described in Section "Materials and Methods." The expression of MHC II relative to the endogenous control gene EF- $1 \alpha$ was calculated for each sample and shown as mean $+\mathrm{SD}$ ( $n=12$, from four independent experiments containing three animals each). Splenocyte cultures were treated with BAFF $(3 \mu \mathrm{g} / \mathrm{ml})$, TNP-LPS $(5 \mu \mathrm{g} / \mathrm{ml})$, or left unstimulated (control) for $48 \mathrm{~h}$, then incubated with Crimson Red fluorescent polystyrene beads ( $1 \mu \mathrm{m}$ diameter) in a ratio of $1: 10$ (cell:beads) for $16 \mathrm{~h}$, and then centrifuged through a $3 \%$ bovine serum albumin $+4.5 \%$ glucose gradient to remove adhered beads. The percentages of phagocytic cells within the lgM+ $\mathrm{B}$ cell compartment was determined (D) as well as the MFI of the beads internalized by lgM+ $\mathrm{B}$ cells in each condition (E) ( $n=12$, from four independent experiments containing three animals each). Dot plots from one representative experiment for each experimental condition are shown (F). Dead cells were not excluded during the flow cytometry analysis, but cell viability was higher than $99 \%$ for IgM+ $\mathrm{B}$ cells and higher than $95 \%$ for other lymphocytes on these experimental settings (Figure S4C in Supplementary Material). Statistical differences were evaluated by a one-way ANOVA followed by a multiple comparison Tukey's test, where ${ }^{* *} p \leq 0.01$ and ${ }^{* \star *} p \leq 0.005$.

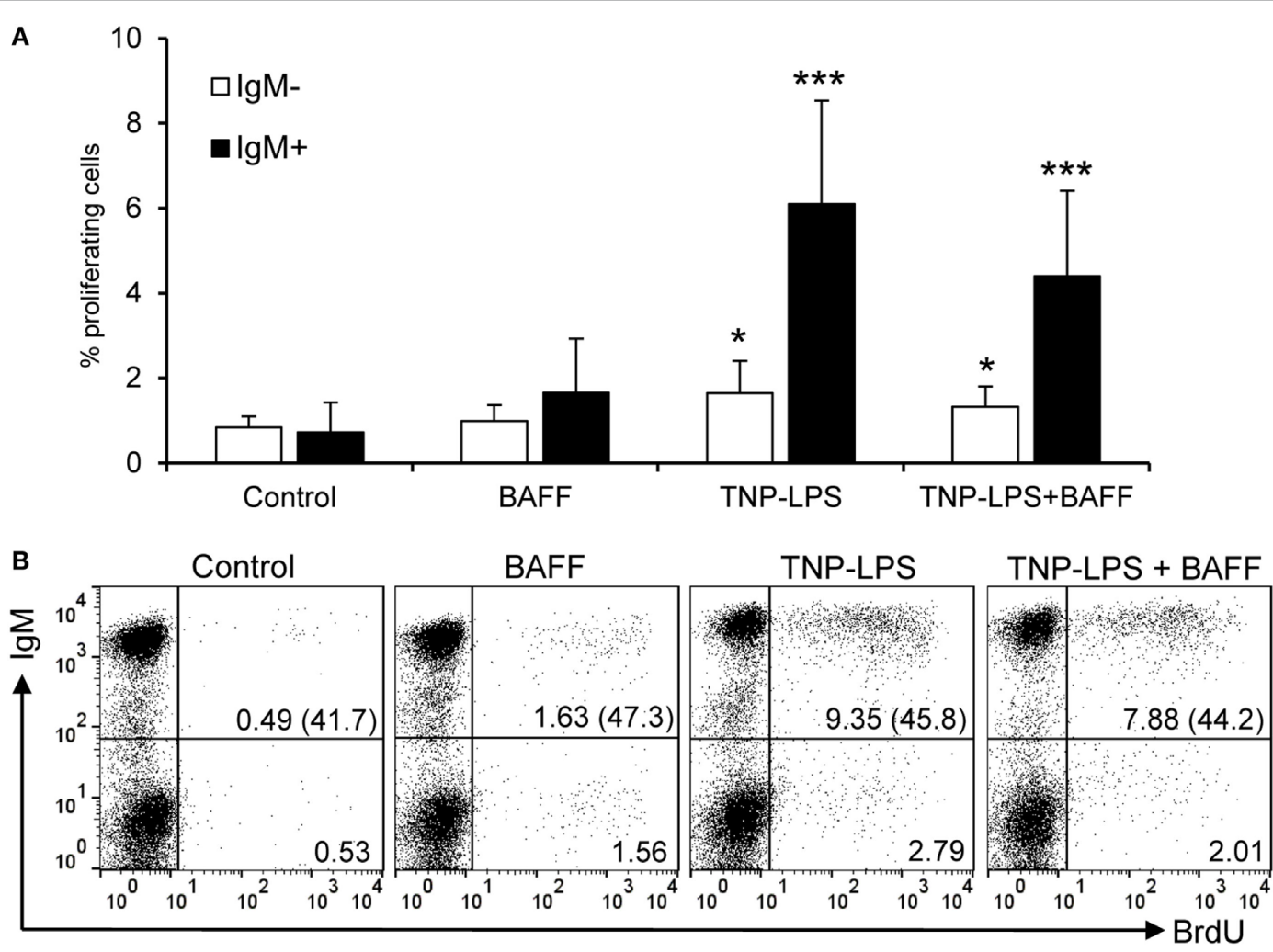

FIGURE 4 | Rainbow trout B cell-activating factor (BAFF) has no lymphoproliferative effects. To test the effect of BAFF on lgM+ $B$ cell proliferation, spleen leukocytes were incubated with BAFF $(3 \mu \mathrm{g} / \mathrm{ml})$, TNP-LPS $(5 \mu \mathrm{g} / \mathrm{ml})$, a combination of both, or left unstimulated (control) for 3 days at $20^{\circ} \mathrm{C}$. After this time, cells were labeled with BrdU and incubated for a further $24 \mathrm{~h}$. The percentage of proliferating (BrdU+) IgM+ B cells was then determined as described in Section "Materials and Methods." Quantification of the proliferating Ig $\mathrm{M}^{-}$and $\operatorname{lgM}^{+}$populations is shown (A) as mean + SD $(n=12$, from four independent experiments containing three animals each), together with a representative dot plot of the flow cytometry analysis (B) number of proliferating lgM+ and lgM+ cells are also indicated within the dot plots. The numbers between brackets represent the total number of lgM+ cells in each case. Dead cells were not excluded during the flow cytometry analysis, but cell viability was higher than 99\% for lgM+ B cells and higher than 95\% for other lymphocytes on these experimental settings (Figure S4C in Supplementary Material). Statistical differences were evaluated by a one-way ANOVA followed by a multiple comparison Tukey's test, where ${ }^{*} p \leq 0.05$ and ${ }^{\star \star \star} p \leq 0.005$.

was visualized in cell cultures from all fish examined individually (Figure 5B), but was not observed when an irrelevant protein with a similar weight and a histidine tag was used (Figure S5B in Supplementary Material). Interestingly, no synergistic effects were observed when splenocytes were incubated with BAFF together with TNP-LPS (Figures 5A,C). Although it would be very interesting to study the effect of BAFF on FACSisolated $\operatorname{IgM}^{+} \mathrm{B}$ cells, no functional studies can be performed 

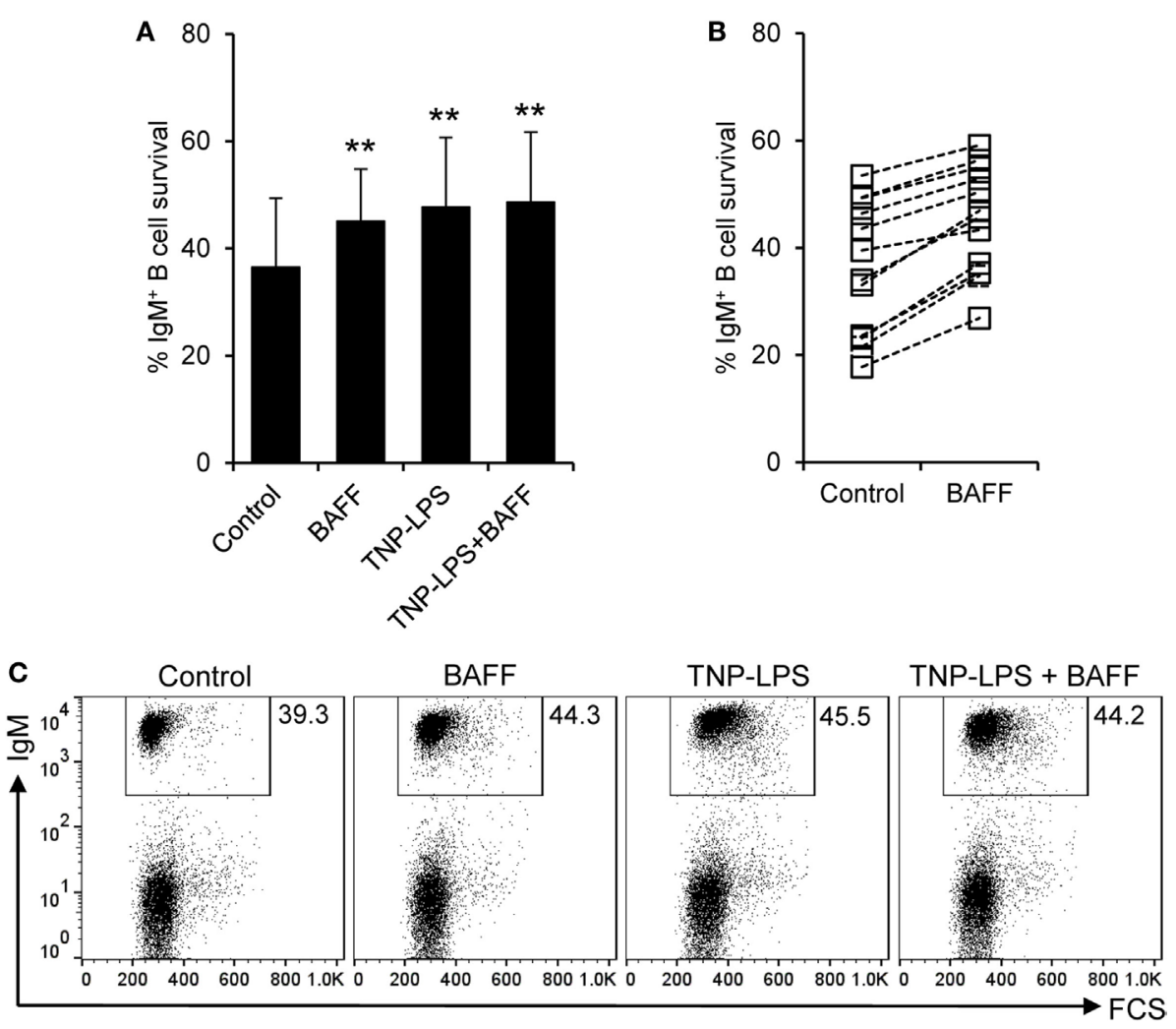

FIGURE 5 | Rainbow trout B cell-activating factor (BAFF) promotes B cell survival. Spleen leukocytes were incubated with recombinant BAFF ( $3 \mu \mathrm{g} / \mathrm{ml})$, TNP-LPS $(5 \mu \mathrm{g} / \mathrm{ml})$, a combination of both, or left unstimulated (control) for 3 days at $20^{\circ} \mathrm{C}$. After this time, cells were labeled with an anti-lgM mAb and analyzed by flow cytometry. The percentage of live $\operatorname{lgM}^{+} B$ cells among the lymphocyte gate was then determined. Quantification of average B cell survival is shown as mean + SD (A), as well as the percentage of survival for each individual fish under control or BAFF stimulation conditions (B) $(n=12$, from four independent experiments containing three animals each). A representative dot plot for each experimental condition is also included (C). Dead cells were not excluded during the flow cytometry analysis, but cell viability was higher than $99 \%$ for IgM+ ${ }^{+} B$ cells and higher than $95 \%$ for other lymphocytes on these experimental settings (Figure S4C in Supplementary Material). Statistical differences were evaluated by a one-way ANOVA followed by a multiple comparison Tukey's test, where ${ }^{* *} p \leq 0.01$.

on isolated $\operatorname{IgM}^{+} \mathrm{B}$ cells, since the only tool available for their isolation is an anti- $\operatorname{IgM} \mathrm{mAb}$, which triggers their activation through BCR cross-linking. Thus, to further demonstrate that BAFF had a direct impact on $\operatorname{IgM}^{+}$and to rule out that the increase on the number of $\operatorname{IgM}^{+}$cells mediated by BAFF was due to a negative effect of the cytokine on $\operatorname{IgM}^{-}$cells, we conducted a similar study, this time also analyzing the number of cells at time $0 \mathrm{~h}$. Our experiments revealed that at time $0 \mathrm{~h}$, the cultures contain a lymphocyte population that accounts for an average $81.9 \pm 7.8 \%$ of the live cells. Although throughout culture, the number of lymphocytes decreased over time, the presence of BAFF in the medium promoted a significant increase in the number of total lymphocytes (Figures S6A,D in Supplementary Material). This increased survival was detected in the $\operatorname{IgM}^{+}$compartment (Figures S6C,E in Supplementary Material) but not in the $\operatorname{IgM}^{-}$(Figures S6B,E in Supplementary Material), thus revealing that the pro-survival effects exerted by BAFF on $\mathrm{IgM}^{+}$cells are not due to negative effects on other populations. These results demonstrate that teleost BAFF, as mammalian BAFF (50), is exclusively a survival factor for $\operatorname{IgM}^{+}$ B cells.

\section{BAFF Increases IgM Production through Increased Survival of IgM+-Secreting Cells}

In mammals, BAFF has been shown to increase the secretion of $\operatorname{IgM}$ and $\operatorname{IgG}$ in the absence of immunization (51). Thus, we aimed to establish if recombinant trout BAFF could increase IgM secretion in splenocyte cultures. To carry this out, we incubated splenocytes for $48 \mathrm{~h}$ with BAFF and/or TNP-LPS, and after that time, we analyzed the number of IgM-secreting cells through ELISPOT. We observed a significant increase in the number of IgM-secreting cells after treatment with either BAFF or TNPLPS, or a combination of both (Figure 6A). This increased number of IgM-secreting cells induced by BAFF was visualized in cell cultures from all fish examined (Figure 6B), but was not observed when a histidine-tagged irrelevant protein with a similar molecular weight was used (Figure S5C in Supplementary Material). Since Blimp-1 is an essential factor for the terminal differentiation of plasma cells in mammals (52), the fact that no upregulation of Blimp-1 expression was observed in sorted $\operatorname{IgM}^{+}$ $\mathrm{B}$ cells after treatment with BAFF (Figure 6C) suggested that IgM plasma cells were not differentiating from resting $B$ cells in response to the cytokine. In mammals, BAFF has been shown 
A

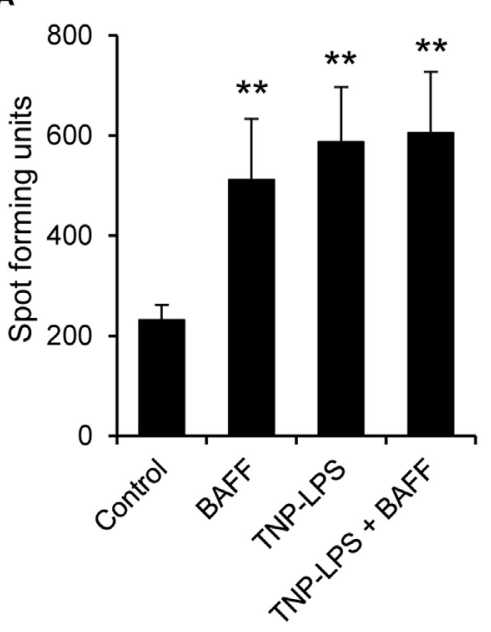

B 800

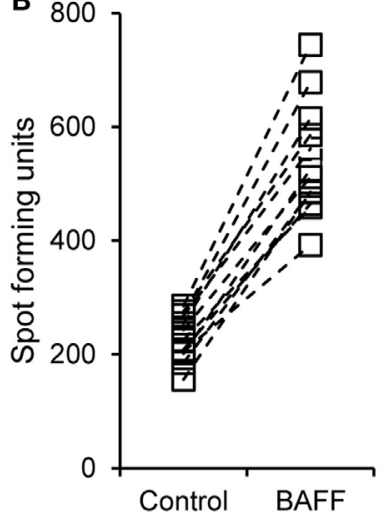

C

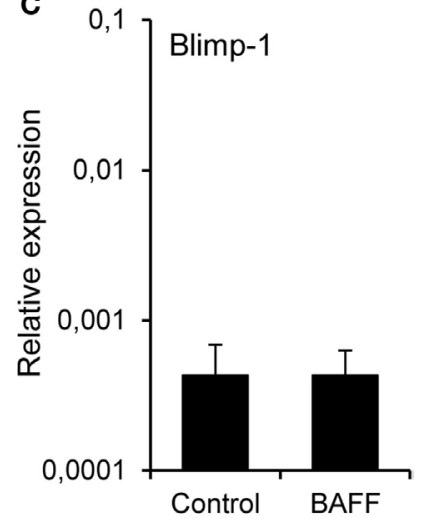

FIGURE 6 | B cell-activating factor (BAFF) increases the number of IgM-secreting cells. (A) Splenocyte cultures were treated with BAFF (3 $\mu$ g/ml), TNP-LPS $(5 \mu \mathrm{g} / \mathrm{ml})$, a combination of both, or left unstimulated (control) for $48 \mathrm{~h}$ and then plated in ELISPOT plates previously coated with anti-trout lgM mAb, for a further $24 \mathrm{~h}$. After incubation, cells were washed away and a biotinylated anti-trout lgM mAb was used to detect numbers of spot forming cells. Quantification of spot forming cells is shown as mean $+\mathrm{SD}(n=12$, from four independent experiments containing three animals each). (B) The number of IgM-secreting cells was also plotted for each individual fish under control or BAFF stimulation conditions. (C) Splenocyte cultures were treated with BAFF $(3 \mu \mathrm{g} / \mathrm{ml})$ or left unstimulated for $24 \mathrm{~h}$ and, then, RNA from IgM+ FACS-isolated B cells was extracted as described in Section "Materials and Methods." The transcription of Blimp-1 relative to the endogenous control EF-1 $\alpha$ was calculated for each sample and shown as mean $+\mathrm{SD}$ ( $n=12$, from four independent experiments containing three animals each). Statistical differences were evaluated by a one-way ANOVA followed by a multiple comparison Tukey's test, where ${ }^{* \star} p \leq 0.01$.

to promote IgM secretion through increased survival of plasma cells (53), so it seemed plausible that the increase in the number of IgM-secreting cells in response to rainbow trout BAFF was a consequence of BAFF promoting the survival of a pre-existing IgM-secreting cell compartment (either plasmablasts or plasma cells) in the spleen. To test this hypothesis, we performed a double staining with anti-IgD and anti-IgM mAbs and analyzed the effect of BAFF on the survival of $\operatorname{IgD}^{+} \mathrm{IgM}^{+}$cells and that of a small subpopulation of $\mathrm{IgD}^{-} \mathrm{IgM}^{+} \mathrm{B}$ cells found in the spleen. We found that both $\operatorname{IgD}^{+} \operatorname{IgM}^{+}$(Figures $7 \mathrm{~A}, \mathbf{B}$ ) and $\operatorname{IgD}^{-} \operatorname{IgM}^{+} \mathrm{B}$ cells (Figures 7A,C) had a significantly increased survival in the presence of BAFF, with consistent increases in all individual fish analyzed (Figures $7 \mathbf{B}, \mathbf{C}$ ). Because in mammals, activated B cells that start their differentiation toward plasmablasts/plasma cells lose IgD in the cell membrane (54), these two B cell subpopulations should correspond with naïve $\mathrm{B}$ cells $\left(\operatorname{IgD}^{+} \operatorname{IgM}^{+}\right)$and plasmablasts/plasma cells $\left(\operatorname{IgD}^{-} \operatorname{IgM}^{+}\right)$. Confirming this premise, we phenotypically characterized these two B cell subpopulations. First, we estimated the size of these cells by means of the MFI of their forward scatter by flow cytometry, since an increase of the cell size is a common feature of antibody-secreting cells (ASCs) (55). As expected, $\operatorname{IgD}^{-} \operatorname{IgM}^{+}$presented a significantly larger size than $\mathrm{IgD}^{+} \mathrm{IgM}^{+} \mathrm{B}$ cells (Figure 7D). Furthermore, we, FACS isolated both $\mathrm{B}$ cell subtypes from the spleen and extracted RNA in order to study their gene expression pattern. Naïve $\operatorname{IgD}^{+} \operatorname{IgM}^{+} \mathrm{B}$ cells had undetectable levels of secreted IgM and high-membrane IgD ( $\mathrm{mb}$ IgD) and Pax5 transcription levels (Figure 7E). On the other hand, $\mathrm{IgD}^{-} \mathrm{IgM}^{+}$cells presented significantly lower levels of $\mathrm{mb}$ $\operatorname{IgD}$ and Pax5 that, along with high mRNA levels of the secreted form of IgM, point to this population as an ASC type. Moreover, levels of Blimp-1 were significantly higher in $\operatorname{IgD}^{-} \operatorname{IgM}^{+}$cells than in naïve $B$ cells (Figure $7 E$ ). These results indicate that there is a tissue resident plasmablast/plasma cell population in the spleen of rainbow trout, and, as in mammals, IgM secretion is increased by BAFF through the increased survival of these IgM-secreting cells.

\section{DISCUSSION}

Fish are poikilotherm animals that regulate their metabolism in response to external temperature. Consequently, their immune system is also dependent on environmental conditions and even though teleost fish are the first animal group in which the complete adaptive immune machinery is present, at low temperatures, such as those at which salmonids usually live, these specific responses are significantly delayed. This, together with the lack of follicular structures in their immune organs, anticipates that, in teleost, the components of the adaptive immune system still retain many innate features and are closely dependent on innate regulatory factors. Given the fact that, in mammals, BAFF is a cytokine produced by innate cells upon antigen sensing, to regulate the survival and differentiation of B cells, especially at extrafollicular foci (56), we hypothesized that teleost B cell function will be tightly regulated by BAFF. Thus, in the current work, we have undertaken an extensive characterization of the effects of BAFF on the functionality of teleost B cells. Before undertaking these functional studies, we performed a transcriptional analysis to study BAFF mRNA levels throughout the different fish tissues in physiological conditions. We found that BAFF expression was highest in spleen, as reported in other fish species, with the 
A

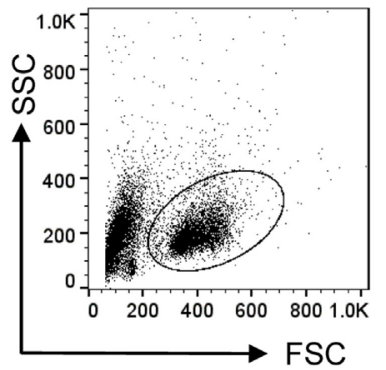

B

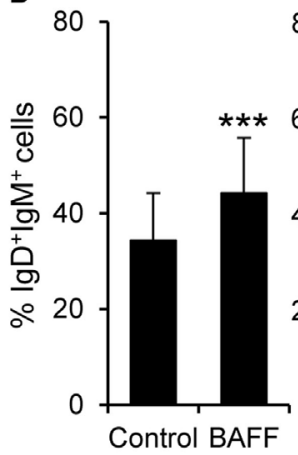

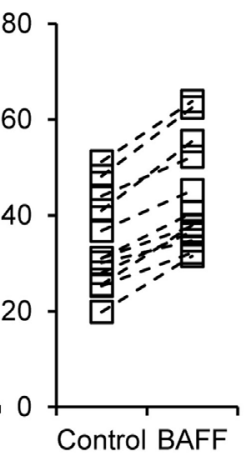

BAFF

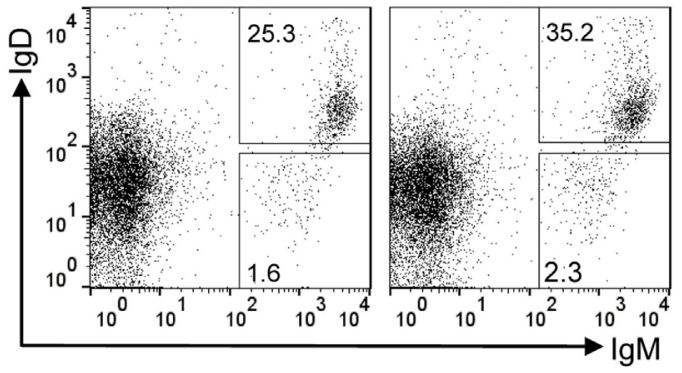

C

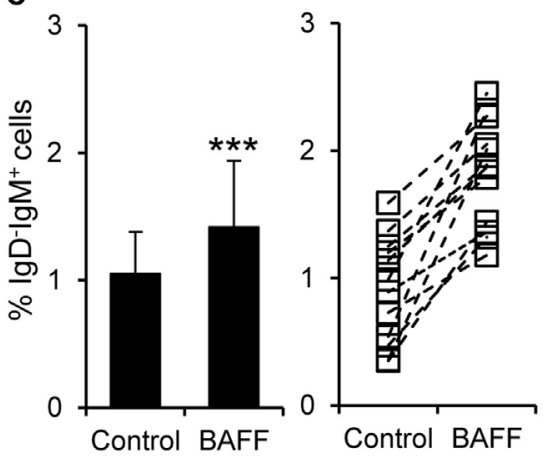

D

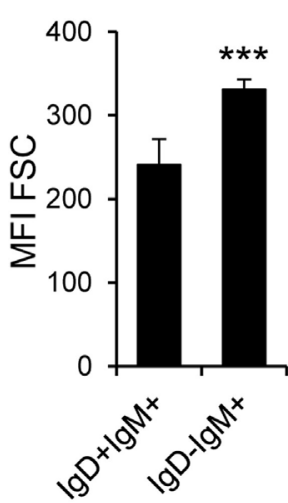

E

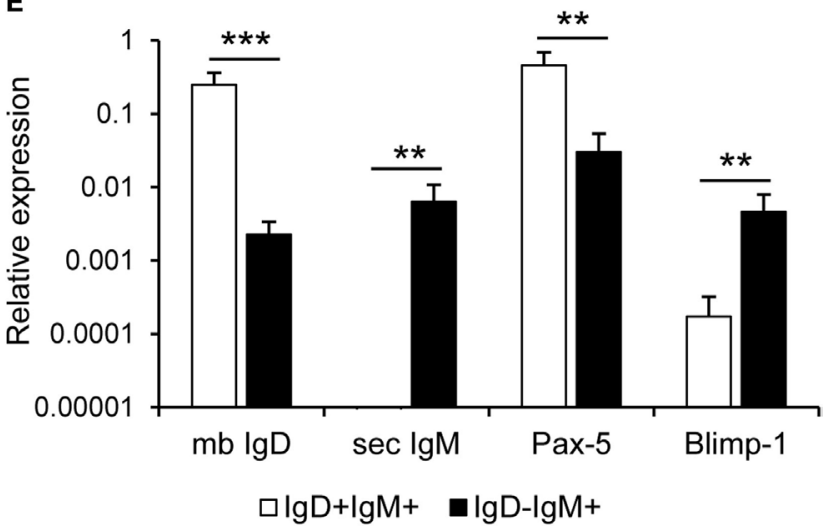

FIGURE 7 | B cell-activating factor (BAFF) promotes the survival of naïve B cells and IgM-secreting cells. (A) Spleen leukocytes were incubated with recombinant BAFF $(3 \mu \mathrm{g} / \mathrm{ml})$ or left unstimulated (control) for 3 days at $20^{\circ} \mathrm{C}$. After this time, cells were labeled with anti-lgD and anti-lgM mAbs and analyzed by flow cytometry. The percentage of live $\lg ^{+} \operatorname{lgM}^{+}$and $\lg \mathrm{D}^{-} \lg \mathrm{M}^{+} \mathrm{B}$ cells among the lymphocyte gate was then determined. Number of cells is annotated within the gates of the representative dot plots shown. Average survival of $\operatorname{lgD}^{+} \operatorname{lgM}^{+} \mathbf{( B )}$ and $\lg D^{-} \operatorname{lgM}^{+} \mathbf{( C )} B$ cell survival is shown (left panels) as well as the percentage of surviving B cells for each individual fish under control or BAFF stimulation conditions [(B,C), right panels]. (D) $\operatorname{lgD}^{+} \lg M^{+}$and $\operatorname{lgD}{ }^{-} \lg M^{+} \mathbf{B}$ cells were gated and the mean fluorescence intensity (MFI) for their forward scatter (FSC) determined ( $n=12$, from four independent experiments containing three animals each). (E) IgD+IgM+ and IgD-lgM+ B cells from the spleen were FACS isolated and RNA extracted. The transcription levels of membrane lgD (mb lgD), secreted lgM (sec lgM) Pax-5, and Blimp-1 relative to the endogenous control EF- $1 \alpha$ were calculated for each sample and shown as mean $+\mathrm{SD}(n=9$, from three independent experiments containing three animals each). Dead cells were not excluded during the flow cytometry analysis, but cell viability was higher than $99 \%$ for lgM+ B cells and higher than 95\% for other lymphocytes on these experimental settings (Figure S4C in Supplementary Material). Statistical differences were evaluated by a one-way ANOVA followed by a multiple comparison Tukey's test, where ${ }^{* \star} p \leq 0.01$ and ${ }^{* \star *} p \leq 0.005$

exception of miiuy croaker, species in which highest BAFF mRNA levels were observed in skin (26). Consequently, our functional assays were performed with splenic $\operatorname{IgM}^{+} \mathrm{B}$ cells.

In addition to providing an extensive characterization of $\mathrm{B}$ cell functions modulated by BAFF in teleost fish, the present study reports a major finding: the fact that, in teleost, a subset of B cells produces BAFF in physiological conditions. This result was confirmed through real-time PCR analysis, flow cytometry, and confocal imaging using a specific mouse polyclonal antibody against recombinant trout BAFF, previously characterized. Although only $7 \%$ of the $\operatorname{IgM}^{+}$B cells produce BAFF as established by flow cytometry, given the high number of $\operatorname{IgM}^{+} B$ cells among 
splenocytes, this population accounts for approximately $28 \%$ of the cells producing BAFF pointing to an important contribution of this population on the homeostasis of the spleen. Of course, it would be possible that some of the B cells in our cultures have been previously exposed to an antigen as the fish used in our study were obtained from a fish farm. It must be noted that the BAFF-producing $\operatorname{IgM}^{+} \mathrm{B}$ cells displayed a phenotype of resting mature B cells with high IgD expression on the cell membrane and transcription of surface $\operatorname{IgM}$ and $\operatorname{IgD}$ at high levels (data not shown), but we cannot discard that some of these cells may be antigen-experienced $\mathrm{B}$ cells, or even plasmablasts/plasma cells, given the fact that IgM-producing plasmablasts retain IgM on the cell membrane $(57,58)$. In mice and humans, BAFF is produced by macrophages, DCs, follicular DCs, stimulated neutrophils, and at low levels by $\mathrm{T}$ cells, but is never produced by resting $B$ cells $(3,8,59-62)$. Interestingly, B cells from B-cell chronic lymphocytic leukemia (63) or non-Hodgkin's lymphoma (64), as well as B cells from patients with autoimmune disorders, namely rheumatoid arthritis (65), systemic lupus erythematosus (66), and primary Sjogren's syndrome (67) also express BAFF, which rescues them from apoptosis in an autocrine loop. B1 cells and pre-B cells have also been shown to contain higher levels of BAFF mRNA when compared to transitional, follicular, or MZ B cells (68). Remarkably, all rabbit spleen B cells, known to express CD5 and consequently regarded as a B1-like population, also express BAFF constitutively (69). Thus, the fact that teleost $B$ cells produce BAFF, adds up to previous evidences that point to the great similarity between teleost B cells and mammalian B1 populations. Interestingly, one of the distinctive features of B1 cells in all species, also shared by teleost B cells, is their extended survival, and this is a characteristic also seen in B cell disorders in which autocrine BAFF production has been reported (63-66). Therefore, BAFF seems to be a key factor involved in the prolonged survival of B1 cells, and this is something that should be further investigated.

Before addressing the effects that BAFF provoked on teleost $B$ cell functions, we analyzed the binding of BAFF to splenocytes. Our results showed that only $8.4 \%$ of the $\mathrm{IgM}^{+} \mathrm{B}$ cells in the spleen were able to bind to recombinant BAFF; however, this percentage went up to $39.2 \%$ when both binding and internalization were determined through confocal microscopy. On the other hand, our experiments also revealed that $3.9 \%$ of the $\mathrm{IgM}^{-}$cells in the rainbow trout spleen also bound recombinant BAFF. Taking into account that $\operatorname{IgT}^{+} \mathrm{B}$ cells in the rainbow trout spleen constitute $25 \%$ of the total B cell population, it seems plausible that these $\mathrm{IgM}^{-}$lymphocytes binding $\mathrm{BAFF}$ are in fact $\operatorname{IgT}^{+} \mathrm{B}$ cells and this is something that should be further explored. The percentage of $B$ cells binding BAFF in the spleen revealed by our experiments seemed surprisingly low when compared to mammals as all splenic human (53) and mouse B cells (70) bind BAFF through BAFF-R, constitutively expressed on the cell surface of all resting $B$ cells. We have very recently demonstrated that rainbow trout splenic $\operatorname{IgM}^{+} \mathrm{B}$ cells transcribe not only BAFF-R but also BCMA (unpublished observations), thus it does not seem probable that this lower capacity to bind exogenous BAFF is a consequence of lower receptor expression levels. Another possible explanation is that BAFF receptors in trout $\mathrm{B}$ cells are already occupied by endogenous BAFF produced constitutively in the spleen. In rabbit, where B cells have been shown to actively produce BAFF, a low BAFF-binding capacity of splenic B cells has also been shown (69). The authors similarly concluded that these cells could not bind recombinant BAFF because the receptors were already occupied with endogenously synthesized BAFF.

$\mathrm{B}$ cells are professional antigen-presenting cells (APCs), which can endocytose antigens through the BCR and effectively present antigens to T cells in an MHC II context (71). In teleost, the high phagocytic capacity of $B$ cells predicts an even higher antigenpresenting capacity than that of mammalian B cells (37), also being capable of presenting particulate antigens. Thus, initially, we studied the effect of BAFF on both the surface MHC II expression levels and the phagocytic capacities of splenic $\operatorname{IgM}^{+}$B cells. We found that BAFF strongly increased surface MHC II expression in $\mathrm{IgM}^{+}$cells, at levels much higher than those reached by TNPLPS-treated $\operatorname{IgM}^{+}$B cells. Because MHC II gene transcription was not upregulated in BAFF-treated cells, it appears that this increase is a consequence of increased translocation of MHC II molecules to the plasma membrane or an augmented half-life of membrane MHC II. A similar increase in surface MHC II expression in B cells in response to BAFF has also been demonstrated in mammals $(18,72)$. Although this increased surface MHC II expression anticipates an increased antigen-presenting capacity of $B$ cells, the uptake of particulate antigen through phagocytosis was not affected by BAFF, indicating that BAFF only regulates the posterior antigen exposure on the membrane.

Focusing further on the effects that BAFF produces on teleost $B$ cells, we observed insignificant proliferative effects, in contrast to the high proliferative effects exerted by TNP-LPS. Despite this, there was a significant increase in $\mathrm{IgM}^{+} \mathrm{B}$ cell survival, at levels similar to those of TNP-LPS, demonstrating that in the absence of additional stimulation, rainbow trout BAFF is exclusively a survival factor for IgM+ $\mathrm{B}$ cells, as occurs in mammals $(11,50)$. This extended survival was observed in naïve $B$ cell populations of the spleen that co-expressed IgM and IgD in the cell membrane as well as in plasmablasts that have lost surface IgD once the differentiation process toward plasmablast/plasma cell has begun. This plasmablast/plasma cell phenotype was confirmed by the enlarged size of these $\operatorname{IgD}^{-} \operatorname{IgM}^{+}$cells, together with the expression of the secreted form of IgM and the increased transcriptional levels of Blimp-1, thus indicating that BAFF can act in different splenic trout B cell subsets, as it happens in mammals (73). This is the first characterization of such B cell subpopulations in teleost by means of surface IgD expression. The extended survival of these plasmablasts/plasma cells is the most probable cause for the increase in the number of IgM-secreting cells observed after BAFF treatment of splenocyte cultures. In mammals, there is some controversy regarding the effects of BAFF on antibody secretion. In mice, the administration of BAFF alone, increased serum IgM and IgA levels, but had no effect on IgG (59), again pointing to preferred BAFF actions outside the GC. On the other hand, transgenic mice overexpressing BAFF had increased IgG levels, while IgM levels were only slightly augmented (72). Finally, when BAFF was administered in combination with a Streptococcus pneumoniae vaccine, IgM, and IgG were only marginally affected, whereas BAFF markedly increased IgA production (51). In trout, 
we have established that BAFF increases the secretion of IgM in the spleen in a Blimp-1-independent fashion, ruling out a role of BAFF as a B cell differentiation factor. This increased IgM production seems to be a direct consequence of the increased survival of pre-existing IgM-secreting cells.

In conclusion, we have demonstrated that different teleost $B$ cell populations respond to BAFF. Splenic $\operatorname{IgM}^{+} B$ cells, the main cell type producing BAFF in this tissue, are able to extend their survival and upregulate their MHC II surface levels in response to the cytokine. Splenic plasmablasts do not produce BAFF in physiological conditions (data not shown) but also have an increased survival rate in response to the cytokine, which results in increased IgM secretion levels. Our results reveal an ancient mechanism through which BAFF regulates B cell function in teleost. To our knowledge, this is the first study that demonstrates this unique regulatory pathway on $\mathrm{B}$ cells under physiological conditions. Thus, our findings unravel the ancient origin of this regulatory mechanism that reemerges in a variety of B cell disorders such as autoimmune diseases or B cell malignancies.

\section{AUTHOR CONTRIBUTIONS}

CT performed data analysis and collaborated in the design of the experiments. LG carried out RNA extractions, cDNA synthesis, and real-time PCRs. LG also assisted RC and AG in tissue sampling

\section{REFERENCES}

1. Cerutti A, Puga I, Cols M. Innate control of B cell responses. Trends Immunol (2011) 32:202-11. doi:10.1016/j.it.2011.02.004

2. Cerutti A, Cols M, Puga I. Activation of B cells by non-canonical helper signals. EMBO Rep (2012) 13:798-810. doi:10.1038/embor.2012.111

3. Craxton A, Magaletti D, Ryan EJ, Clark EA. Macrophage- and dendritic cell-dependent regulation of human B-cell proliferation requires the TNF family ligand BAFF. Blood (2003) 101:4464-71. doi:10.1182/blood-200210-3123

4. Scapini P, Carletto A, Nardelli B, Calzetti F, Roschke V, Merigo F, et al. Proinflammatory mediators elicit secretion of the intracellular B-lymphocyte stimulator pool (BLyS) that is stored in activated neutrophils: implications for inflammatory diseases. Blood (2005) 105:830-7. doi:10.1182/ blood-2004-02-0564

5. MacLennan I, Vinuesa C. Dendritic cells, BAFF, and APRIL: innate players in adaptive antibody responses. Immunity (2002) 17:235-8. doi:10.1016/ S1074-7613(02)00398-9

6. Vora KA, Wang LC, Rao SP, Liu ZY, Majeau GR, Cutler AH, et al. Cutting edge: germinal centers formed in the absence of $\mathrm{B}$ cell-activating factor belonging to the TNF family exhibit impaired maturation and function. J Immunol (2003) 171:547-51. doi:10.4049/jimmunol.171.2.547

7. Schneider P. The role of APRIL and BAFF in lymphocyte activation. Curr Opin Immunol (2005) 17:282-9. doi:10.1016/j.coi.2005.04.005

8. Nardelli B, Belvedere O, Roschke V, Moore PA, Olsen HS, Migone TS, et al. Synthesis and release of B-lymphocyte stimulator from myeloid cells. Blood (2001) 97:198-204. doi:10.1182/blood.V97.1.198

9. Gross JA, Johnston J, Mudri S, Enselman R, Dillon SR, Madden K, et al. TACI and BCMA are receptors for a TNF homologue implicated in B-cell autoimmune disease. Nature (2000) 404:995-9. doi:10.1038/35010115

10. Thompson JS, Bixler SA, Qian F, Vora K, Scott ML, Cachero TG, et al. BAFF-R, a newly identified TNF receptor that specifically interacts with BAFF. Science (2001) 293:2108-11. doi:10.1126/science.1061965

11. Schneider P, Mackay F, Steiner V, Hofmann K, Bodmer JL, Holler N, et al. BAFF, a novel ligand of the tumor necrosis factor family, stimulates B cell growth. J Exp Med (1999) 189:1747-56. doi:10.1084/jem.189.11.1747 and processing. RC performed the cell proliferation and survival experiments. AG performed the rest of the experimental work, performed data analysis, and designed the experiments together with CT. CT and AG wrote the paper.

\section{ACKNOWLEDGMENTS}

We would like to thank Ana Villa for technical assistance provided for confocal microscopy experiments and Francisco Mateos for the help provided for mice immunizations. The authors want to thank Erin Bromage and Uwe Fischer for providing the anti-IgD and anti-CD8 antibodies, respectively.

\section{FUNDING}

This work was supported by the European Research Council (ERC Starting Grant 2011280469 ) and by project AGL201454456-JIN from the Spanish Ministry of Economy and Competitiveness (MINECO).

\section{SUPPLEMENTARY MATERIAL}

The Supplementary Material for this article can be found online at http://journal.frontiersin.org/article/10.3389/fimmu. 2017.00295/full\#supplementary-material.

12. Batten M, Groom J, Cachero TG, Qian F, Schneider P, Tschopp J, et al. BAFF mediates survival of peripheral immature B lymphocytes. J Exp Med (2000) 192:1453-66. doi:10.1084/jem.192.10.1453

13. Shulga-Morskaya S, Dobles M, Walsh ME, Ng LG, Mackay F, Rao SP, et al. B cell-activating factor belonging to the TNF family acts through separate receptors to support B cell survival and $\mathrm{T}$ cell-independent antibody formation. JImmunol (2004) 173:2331-41. doi:10.4049/jimmunol. 173.4.2331

14. Mackay F, Schneider P. TACI, an enigmatic BAFF/APRIL receptor, with new unappreciated biochemical and biological properties. Cytokine Growth Factor $\operatorname{Rev}(2008)$ 19:263-76. doi:10.1016/j.cytogfr.2008.04.006

15. von Bulow GU, Van Deursen JM, Bram RJ. Regulation of the T-independent humoral response by TACI. Immunity (2001) 14:573-82. doi:10.1016/ S1074-7613(01)00130-3

16. Mantchev GT, Cortesao CS, Rebrovich M, Cascalho M, Bram RJ. TACI is required for efficient plasma cell differentiation in response to T-independent type 2 antigens. J Immunol (2007) 179:2282-8. doi:10.4049/ jimmunol.179.4.2282

17. O'Connor BP, Raman VS, Erickson LD, Cook WJ, Weaver LK, Ahonen C, et al. BCMA is essential for the survival of long-lived bone marrow plasma cells. J Exp Med (2004) 199:91-8. doi:10.1084/jem.20031330

18. Yang M, Hase H, Legarda-Addison D, Varughese L, Seed B, Ting AT. B cell maturation antigen, the receptor for a proliferation-inducing ligand and $\mathrm{B}$ cell-activating factor of the TNF family, induces antigen presentation in B cells. J Immunol (2005) 175:2814-24. doi:10.4049/jimmunol.175.5.2814

19. Bossen C, Cachero TG, Tardivel A, Ingold K, Willen L, Dobles M, et al. TACI, unlike BAFF-R, is solely activated by oligomeric BAFF and APRIL to support survival of activated B cells and plasmabflasts. Blood (2008) 111:1004-12. doi:10.1182/blood-2007-09-110874

20. Glenney GW, Wiens GD. Early diversification of the TNF superfamily in teleosts: genomic characterization and expression analysis. J Immunol (2007) 178:7955-73. doi:10.4049/jimmunol.178.12.7955

21. Liang Z, Kong Y, Luo C, Shen Y, Zhang S. Molecular cloning, functional characterization and phylogenetic analysis of B-cell activating factor in zebrafish (Danio rerio). Fish Shellfish Immunol (2010) 29:233-40. doi:10.1016/ j.fsi.2010.03.006 
22. Ai H, Shen Y, Min C, Pang S, Zhang J, Zhang S, et al. Molecular structure, expression and bioactivity characterization of TNF13B (BAFF) gene in mefugu, Takifugu obscurus. Fish Shellfish Immunol (2011) 30:1265-74. doi:10.1016/j.fsi.2011.03.020

23. Cui XW, Li JF, Xiao W, Xuan Y, Tian AY, Xu XZ, et al. Molecular cloning, expression and functional analysis of TNF13b (BAFF) in Japanese sea perch, Lateolabrax japonicus. Int Immunopharmacol (2012) 12:34-41. doi:10.1016/ j.intimp.2011.10.009

24. Pandit NP, Shen Y, Wang W, Chen Y, Li J. Identification of TNF13b (BAFF) gene from grass carp (Ctenopharyngodon idella) and its immune response to bacteria and virus. Dev Comp Immunol (2013) 39:460-4. doi:10.1016/ j.dci.2013.01.004

25. Xiao W, Long W, Liu GY, Sui CL, Guo XR, Tian A, et al. Molecular cloning, expression and functional analysis of B-cell activating factor (BAFF) in yellow grouper, Epinephelus awoara. Mol Immunol (2014) 59:64-70. doi:10.1016/ j.molimm.2014.01.005

26. Meng F, Sun Y, Xu T. Comparative genomic of the BAFF and BAFF-like genes and immune response to bacteria of miiuy croaker (Miichthys miiuy). Fish Shellfish Immunol (2015) 43:191-9. doi:10.1016/j.fsi.2014.12.022

27. Sun Y, Sun L. CsBAFF, a teleost B cell activating factor, promotes pathogen-induced innate immunity and vaccine-induced adaptive immunity. PLoS One (2015) 10:e0136015. doi:10.1371/journal.pone.0136015

28. Liu H, Zhang J, Li J, Song J, Zhang S. Molecular structure, distribution, and immunology function of TNFSF13B (BAFF) in Nile tilapia (Oreochromis niloticus). Fish Shellfish Immunol (2016) 51:240-50. doi:10.1016/j.fsi.2016. 02.026

29. Godahewa GI, Perera NC, Umasuthan N, Wan Q, Whang I, Lee J. Molecular characterization and expression analysis of B cell activating factor from rock bream (Oplegnathus fasciatus). Dev Comp Immunol (2016) 55:1-11. doi:10.1016/j.dci.2015.10.004

30. Ren W, Pang S, You F, Zhou L, Zhang S. The first BAFF gene cloned from the cartilaginous fish. Fish Shellfish Immunol (2011) 31:1088-96. doi:10.1016/ j.fsi.2011.09.013

31. Li R, Dooley H, Wang T, Secombes CJ, Bird S. Characterisation and expression analysis of B-cell activating factor (BAFF) in spiny dogfish (Squalus acanthias): cartilaginous fish BAFF has a unique extra exon that may impact receptor binding. Dev Comp Immunol (2012) 36:707-17. doi:10.1016/j.dci.2011. 11.010

32. Li R, Redmond AK, Wang T, Bird S, Dooley H, Secombes CJ. Characterisation of the TNF superfamily members CD40L and BAFF in the small-spotted catshark (Scyliorhinus canicula). Fish Shellfish Immunol (2015) 47:381-9. doi:10.1016/j.fsi.2015.09.033

33. Zapata AG, Torroba M, Vicente A, Varas A, Sacedon R, Jimenez E. The relevance of cell microenvironments for the appearance of lympho-haemopoietic tissues in primitive vertebrates. Histol Histopathol (1995) 10:761-78.

34. Salinas I, Zhang YA, Sunyer JO. Mucosal immunoglobulins and B cells of teleost fish. Dev Comp Immunol (2011) 35:1346-65. doi:10.1016/j.dci.2011. 11.009

35. Zhang YA, Salinas I, Li J, Parra D, Bjork S, Xu Z, et al. IgT, a primitive immunoglobulin class specialized in mucosal immunity. Nat Immunol (2010) 11:827-35. doi:10.1038/ni.1913

36. Xu Z, Parra D, Gomez D, Salinas I, Zhang YA, Von Gersdorff Jorgensen L, et al. Teleost skin, an ancient mucosal surface that elicits gut-like immune responses. Proc Natl Acad Sci U S A (2013) 110:13097-102. doi:10.1073/ pnas. 1304319110

37. Li J, Barreda DR, Zhang YA, Boshra H, Gelman AE, Lapatra S, et al. B lymphocytes from early vertebrates have potent phagocytic and microbicidal abilities. Nat Immunol (2006) 7:1116-24. doi:10.1038/ni1389

38. Parra D, Rieger AM, Li J, Zhang YA, Randall LM, Hunter CA, et al. Pivotal advance: peritoneal cavity B-1 B cells have phagocytic and microbicidal capacities and present phagocytosed antigen to CD4+ T cells. J Leukoc Biol (2012) 91:525-36. doi:10.1189/jlb.0711372

39. Abos B, Castro R, Pignatelli J, Luque A, Gonzalez L, Tafalla C. Transcriptional heterogeneity of IgM+ cells in rainbow trout (Oncorhynchus mykiss) tissues. PLoS One (2013) 8:e82737. doi:10.1371/journal.pone.0082737

40. Abos B, Castro R, Gonzalez Granja A, Havixbeck JJ, Barreda DR, Tafalla C. Early activation of teleost B cells in response to rhabdovirus infection. J Virol (2015) 89:1768-80. doi:10.1128/JVI.03080-14
41. Castro R, Abos B, Gonzalez L, Aquilino C, Pignatelli J, Tafalla C. Molecular characterization of CD9 and CD63, two tetraspanin family members expressed in trout B lymphocytes. Dev Comp Immunol (2015) 51:116-25. doi:10.1016/ j.dci.2015.03.002

42. Bonifacino JS, Dell'angelica EC, Springer TA. Immunoprecipitation. Curr Protoc Mol Biol (2001) 10:Unit 1016. doi:10.1002/0471142727.mb1016s48

43. Castro R, Bromage E, Abos B, Pignatelli J, Gonzalez Granja A, Luque A, et al. CCR7 is mainly expressed in teleost gills, where it defines an IgD+IgM- B lymphocyte subset. J Immunol (2014) 192:1257-66. doi:10.4049/ jimmunol.1302471

44. Granja AG, Leal E, Pignatelli J, Castro R, Abos B, Kato G, et al. Identification of teleost skin CD8alpha+ dendritic-like cells, representing a potential common ancestor for mammalian cross-presenting dendritic cells. J Immunol (2015) 195:1825-37. doi:10.4049/jimmunol.1500322

45. Farrell AP, Macleod KR, Driedzic WR, Wood S. Cardiac performance in the in situ perfused fish heart during extracellular acidosis: interactive effects of adrenaline. J Exp Biol (1983) 107:415-29.

46. Ganassin RC, Bols NC. A stromal cell line from rainbow trout spleen, RTS34ST, that supports the growth of rainbow trout macrophages and produces conditioned medium with mitogenic effects on leukocytes. In Vitro Cell Dev Biol Anim (1999) 35:80-6. doi:10.1007/s11626-999-0005-9

47. Wang T, Bird S, Koussounadis A, Holland JW, Carrington A, Zou J, et al. Identification of a novel IL-1 cytokine family member in teleost fish. J Immunol (2009) 183:962-74. doi:10.4049/jimmunol.0802953

48. Hong S, Li R, Xu Q, Secombes CJ, Wang T. Two types of TNF-alpha exist in teleost fish: phylogeny, expression, and bioactivity analysis of type-II TNFalpha3 in rainbow trout Oncorhynchus mykiss. J Immunol (2013) 191:5959-72. doi:10.4049/jimmunol.1301584

49. Matsuki Y, Ohmura-Hoshino M, Goto E, Aoki M, Mito-Yoshida M, Uematsu $\mathrm{M}$, et al. Novel regulation of MHC class II function in B cells. EMBO J (2007) 26:846-54. doi:10.1038/sj.emboj.7601556

50. Mackay F, Browning JL. BAFF: a fundamental survival factor for B cells. Nat Rev Immunol (2002) 2:465-75. doi:10.1038/nri844

51. Do RK, Chen-Kiang S. Mechanism of BLyS action in B cell immunity. Cytokine Growth Factor Rev (2002) 13:19-25. doi:10.1016/S1359-6101(01)00025-9

52. Kallies A, Hasbold J, Tarlinton DM, Dietrich W, Corcoran LM, Hodgkin $\mathrm{PD}$, et al. Plasma cell ontogeny defined by quantitative changes in blimp-1 expression. J Exp Med (2004) 200:967-77. doi:10.1084/jem.20040973

53. Avery DT, Kalled SL, Ellyard JI, Ambrose C, Bixler SA, Thien M, et al. BAFF selectively enhances the survival of plasmablasts generated from human memory B cells. J Clin Invest (2003) 112:286-97. doi:10.1172/JCI18025

54. Victora GD, Nussenzweig MC. Germinal centers. Annu Rev Immunol (2012) 30:429-57. doi:10.1146/annurev-immunol-020711-075032

55. Oracki SA, Walker JA, Hibbs ML, Corcoran LM, Tarlinton DM. Plasma cell development and survival. Immunol Rev (2010) 237:140-59. doi:10.1111/j.1600-065X.2010.00940.x

56. Darce JR, Arendt BK, Wu X, Jelinek DF. Regulated expression of BAFF-binding receptors during human B cell differentiation. J Immunol (2007) 179:7276-86. doi:10.4049/jimmunol.179.11.7276

57. Pinto D, Montani E, Bolli M, Garavaglia G, Sallusto F, Lanzavecchia A, et al. A functional BCR in human IgA and IgM plasma cells. Blood (2013) 121:4110-4. doi:10.1182/blood-2012-09-459289

58. Abos B, Wang T, Castro R, Granja AG, Leal E, Havixbeck J, et al. Distinct differentiation programs triggered by IL- 6 and LPS in teleost $\operatorname{IgM}(+)$ B cells in the absence of germinal centers. Sci Rep (2016) 6:30004. doi:10.1038/ srep30004

59. Moore PA, Belvedere O, Orr A, Pieri K, Lafleur DW, Feng P, et al. BLyS: member of the tumor necrosis factor family and B lymphocyte stimulator. Science (1999) 285:260-3. doi:10.1126/science.285.5425.260

60. Scapini P, Nardelli B, Nadali G, Calzetti F, Pizzolo G, Montecucco C, et al. G-CSF-stimulated neutrophils are a prominent source of functional BLyS. J Exp Med (2003) 197:297-302. doi:10.1084/jem.20021343

61. El Shikh ME, El Sayed RM, Szakal AK, Tew JG. T-independent antibody responses to T-dependent antigens: a novel follicular dendritic cell-dependent activity. J Immunol (2009) 182:3482-91. doi:10.4049/jimmunol.0802317

62. El Shikh ME, El Sayed RM, Sukumar S, Szakal AK, Tew JG. Activation of B cells by antigens on follicular dendritic cells. Trends Immunol (2010) 31:205-11. doi:10.1016/j.it.2010.03.002 
63. Kern C, Cornuel JF, Billard C, Tang R, Rouillard D, Stenou V, et al. Involvement of BAFF and APRIL in the resistance to apoptosis of B-CLL through an autocrine pathway. Blood (2004) 103:679-88. doi:10.1182/blood-2003-02-0540

64. He B, Chadburn A, Jou E, Schattner EJ, Knowles DM, Cerutti A. Lymphoma B cells evade apoptosis through the TNF family members BAFF/BLyS and APRIL. J Immunol (2004) 172:3268-79. doi:10.4049/jimmunol.172.8.5128-c

65. Nakajima K, Itoh K, Nagatani K, Okawa-Takatsuji M, Fujii T, Kuroki $\mathrm{H}$, et al. Expression of BAFF and BAFF-R in the synovial tissue of patients with rheumatoid arthritis. Scand J Rheumatol (2007) 36:365-72. doi:10.1080/03009740701286615

66. Chu VT, Enghard P, Schurer S, Steinhauser G, Rudolph B, Riemekasten G, et al. Systemic activation of the immune system induces aberrant BAFF and APRIL expression in B cells in patients with systemic lupus erythematosus. Arthritis Rheum (2009) 60:2083-93. doi:10.1002/art.24628

67. Daridon C, Devauchelle V, Hutin P, Le Berre R, Martins-Carvalho C, Bendaoud B, et al. Aberrant expression of BAFF by B lymphocytes infiltrating the salivary glands of patients with primary Sjogren's syndrome. Arthritis Rheum (2007) 56:1134-44. doi:10.1002/art.22458

68. Chu VT, Enghard P, Riemekasten G, Berek C. In vitro and in vivo activation induces BAFF and APRIL expression in B cells. J Immunol (2007) 179:5947-57. doi:10.4049/jimmunol.179.9.5947

69. Yeramilli VA, Knight KL. Requirement for BAFF and APRIL during B cell development in GALT. J Immunol (2010) 184:5527-36. doi:10.4049/ jimmunol.1000146
70. Schiemann B, Gommerman JL, Vora K, Cachero TG, Shulga-Morskaya S, Dobles M, et al. An essential role for BAFF in the normal development of B cells through a BCMA-independent pathway. Science (2001) 293:2111-4. doi:10.1126/science.1061964

71. Rodriguez-Pinto D. B cells as antigen presenting cells. Cell Immunol (2005) 238:67-75. doi:10.1016/j.cellimm.2006.02.005

72. Mackay F, Woodcock SA, Lawton P, Ambrose C, Baetscher M, Schneider P, et al. Mice transgenic for BAFF develop lymphocytic disorders along with autoimmune manifestations. J Exp Med (1999) 190:1697-710. doi:10.1084/ jem.190.11.1697

73. Mackay F, Schneider P. Cracking the BAFF code. Nat Rev Immunol (2009) 9:491-502. doi:10.1038/nri2572

Conflict of Interest Statement: The authors declare that the research was conducted in the absence of any commercial or financial relationships that could be construed as a potential conflict of interest.

Copyright (c) 2017 Tafalla, González, Castro and Granja. This is an open-acces article distributed under the terms of the Creative Commons Attribution License (CC BY). The use, distribution or reproduction in other forums is permitted, provided the original author(s) or licensor are credited and that the original publication in this journal is cited, in accordance with accepted academic practice. No use, distribution or reproduction is permitted which does not comply with these terms. 